\title{
DE KOEBOES IN DE ONDER-AFDEELING MOESI ILIR EN KOEBOESTREKEN.
}

\author{
DOOR
}

\author{
H. H. KEEREWEER. ${ }^{1}$ )
}

Afkomst, stam-, klasse-indeeling.

Mijn voorganger heeft in zijn memorie 3 groepen onderscheiden waarin de bevolking dezer onderafdeeling margagewijze kan worden gesplitst, te weten:

1e. de Moesi-marga's: Sanga Desa, Poendjoeng, Lawang Wetan, Mantri Melajoe, E pi 1, Teloek Kidjing, Soengei Keroeh, Pinggap.

2e. de Koeboe-marga's: Batang Hari Leko, Koeboe Toengkal Oeloe, Koeboe Bajat, Koeboe Lalan, Dawas, Soepat, Babat.

3e. de marga's Penoekal en Abab.

De door mij gevolgde indeeling wijkt eenigermate af van de bovenstaande:

Epil, hoewel thans door gemakkelijke verbinding, huwelijken enz. op de Moesi-marga's georiënteerd, behoort, wat afkomst betreft,

1) Het hier gebodene is getrokken uit de „memorie van overgave”, door den jong gestorven schrijver opgesteld als aftredend Controleur van de onderafdeeling Moesi Iir en Koeboestreken, waarover hij van 12 October 1936-16 Juli 1938 het bestuur had gevoerd. Na genoten Europeesch verlof benoemd tot secretaris van de Westerafdeeling van Borneo, is hij, kort na aankomst op zijn nieuwe standplaats Pontianak, den 23en April 1939 op 31-jarigen leeftijd overleden, waardoor een nauwelijks over het beginstadium gevorderde, veel belovende ambtelijke loopbaan ontijdig afgebroken werd. - De recente, in de memorie geboekstaafde gegevens over deze Koeboes, - dezelfde, die een dertigtal jaren geleden ook door C. J. van Dongen in zijne bekende opstellen in deelen 63 en 67 dezer Bijdragen beschreven werden -, leken van genoeg belang om ze hier op te nemen. Enkele daaronder - zoo b.v. de vuurdans van den malim te Meranti Pandjang - waren nog niet bekend, andere wijken in verschillende opzichten van Van Dongen's beschrijving af. Zij vormen aldus een belangrijk vergelijkingsmateriaal, dat den lezer in staat stelt er zich rekenschap van te geven, in hoeverre in het leven van dit interessante Koeboe-volkje zich de laatste dertig jaren veranderingen ten goede of ten kwade hebben voorgedaan. 
niet tot deze groep. De marga Epil heeft namelijk dezelfde stam vader(s) als Babat en Soepat.

De marga Pinggap is slechts ten deele op de Moesi-marga's georiënteerd. Vroeger konden 2 doesoens gerekend worden te behooren tot de inwoners der Moesi-marga's, te weten Tanah Abang (de pasirahdoesoen) en Pengatoeran. De pojang van laatstgenoemde doesoen was afkomstig van Kasmaran (Lawang Wetan). Deze doesoen was een conglomeraat van lieden afkomstig van Rawas en van Sanga Desa. Thans is de doesoen Pengatoeran zóó ver van de invloedssfeer der Moesi-marga's af gelegen, dat genoemde doesoen niet meer daartoe behoorend kan worden gerekend, zoodat dus van de marga Pinggap resteert de doesoen Tanah Abang, welke binnen de sfeer der Moesi-marga's valt. De overige doesoens, te weten: Pinggap, Loeboek Boeah, Soengei Napal en de nederzetting Talang Saoet en Talang Boeloeh kunnen naar de aard en ontwikkeling der bevolking gerekend worden tot de Koeboe-streken.

Bij de Koeboemarga's zijn door mijn voorganger ondergebracht de marga's Dawas, Soepat en Babat. Deze groepeering berust kenkelijk op de ressorteering van genoemde marga's onder de toenmalige onderafdeeling Banjoeasin en Koeboestreken (Talang Betoetoe). Ten rechte behooren Soepat en Babat krachtens afkomst zeker niet tot de Koeboe-marga's. Hoewel Dazwas gedeeltelijk daarbij zou kunnen worden ondergebracht, dient deze marga, in verband met de belangrijke vermenging der bevolking met lieden van de kota Palembang en de bovenlanden van Palembang, n.h.v. tot een afzondergelijke groep gerekend te worden.

De indeeling wordt, met inachtneming van het bovenstaande, aldus:

1e. de Moesi-marga's: Sanga Desa, Poendjoeng, Lawang Wetan, Teloek Kidjing, Soengei Keroeh, de doesoen Tanah Abang van de marga Pinggap.

2e. de marga's : Epil, Babat, Soepat.

3e. de marga Dawas.

4e. de marga's Penoekal en Abab.

5e. de Koeboe-marga's: Batang Hari Leko, Koeboe Toengkal Oeloe, Koeboe Bajat, Koeboe Lalan, de doesoens Pinggap, Pengatoeran, Loeboek, Boeah, Soengei Napal en de vestigingen Talang Saoet en Talang Boeloeh van de marga Pinggap.

De hierboven weergegeven indeeling is slechts van waarde voor het verkrijgen van een globaal overzicht van de afkomst en onder- 
linge samenhang der bevolking in deze onderafdeeling; het verschil in afkomst is uiteraard voortdurend verflauwd door vermenging der verschillende bevolkingsgroepen, bijvoorbeeld door verhuizing en huwelijken, gemeenschappelijke handelsbelangen, tengevolge waarvan de verschillen in taal of dialect en gewoonten geleidelijk geringer werden.

a. Geschiedenis.

\section{De Koeboe-marga's.}

De oorspronkelijke inwoners dezer marga's zijn Koeboes. Hun afkomst is als volgt: Ongeveer 150 jaren geleden is een Koeboestam de Soengei Koempé, een zijrivier van de Batang Hari (residentie Djambi), opgevaren tot aan de oorsprong van de Soengei Koempé. Van hieruit trokken zij naar de Oeloetoeloeng Soengei Kepahiang (de bronriviertjes van de Soengei Kepahiang), welke rivier in de Lalanrivier uitstroomt. Van de Soengei Kapahiang trok de stam verder naar de Soengei Bakoeng en naar de Baharrivier (Moeara Bahar). Van hieruit splitste zich de stam. Een gedeelte voer de Bajatrivier op; anderen vestigden zich aan de Oeloe-Bahar (residentie Djambi) en een derde gedeelte zakte de Lalanrivier af.

Ten tijde van de beroemde sultane Ratoe Sinoehoen werden aan de Koeboes piagams uitgereikt, te weten: 1. Eén aan Sinom van Bajat, die tot pasirah werd verheven. 2. Eén aan Lagi, die tot pasirah van Koeboe Lalan werd aangesteld. 3. Eén op karbouwenhoorn geschreven, aan de lieden van de Oeloe-Bahar (Djambi).

Dat deze Koeboes een zwervend bestaan geleid hebben blijkt wel uit de volgende opsomming. Van de Oeloe Kepahiang trok men near de Oeloe Soengei Bakoeng (zijrivier van de Lalan). Hierna vestigde men zich aan de rechteroever van de Lalan en stichtte daar de nederzetting Kelapa Sebatang. Van Kelapa Sebatang verhuisde men naar Koenangan, aan de rechteroever van de Soengei Merang (zijrivier van de Lalan). Van Koenangan keerde men terug naar de Lalanrivier waar Soenoeran werd gesticht. Van Soenoeran voer men naar Ketapi en vandaar uit werd $\mathrm{Njarang}$ Toea gesticht. Njarang Toea werd alras verlaten; de nieuwe vestiging heette Njarang Moeda. In 1928 werd deze nederzetting verlaten en trok men naar Bakoeng. Ten aanzien van de afkomst en verdere geschiedenis van Sinom van Bajat (zie boven) zij nog het volgende vermeld. Oorspronkelijk leefde bij de Bajatrivier een Koeboehoofd, genaamd Sinom te Kelapa

D1. 99. 
Sebatang. (Deze nederzetting moet dus een andere zijn dan Kelapa Sebatang aan de Lalan-rivier; zie boven). Voortbouwende op de mededeelingen van de lieden van Mangsang (Koeboe Lalan) meen ik te moeten aannemen dat deze Sinom zijn afkomst herleidde tot de bovengenoemde nederzetting aan de Soengei Koempé (Djambi). Immers te Moeara Bahar is de oorspronkelijke Koeboestam in drie deelen gesplitst, waarvan één gedeelte naar de Bajatstreek trok. De benaming Kelapa Sebatang te Bajat is waarschijnlijk met opzet genoemd naar de moederdoesoen (of -nederzetting) van dien naam aan de Lalanrivier. Te Kelapa Sebatang ontmoette Sinom een uitgeweken Palembanger(?) Karsoedi, die hem het nut van de klapperboom en klappervruchten leerde kennen. $\mathrm{Op} \pm 1 \mathrm{~K} . \mathrm{M}$. afstand van Kelapa Sebatang werd daarop een nieuwe nederzetting gesticht, genaamd Kelapa Banjak, omdat men hier veel klappers plantte. Te Kelapa Banjak verscheen een zekere Temenggoeng, afkomstig van de Belidastreek, doesoen Tjambai (Ogan Ilir). Hij was nog vrijgezel aangezien hij geen geschikte levensgezellin kon vinden. Hij zou van Tjambai zijn weggeloopen omdat pogingen om hem te besnijden mislukt waren, aangezien zijn geslachtsdeel zóó abnormaal groot en hard was, dat elk mes of ander wapen daarop afstuitte $\left.{ }^{1}\right)$. Te Kelapa Banjak wijzigde Temenggoeng uit schaamte zijn naam in Koeboe Lebar Telapak (dus Koeboe-breede-voetzool). Hij moet een man van buitengewone lichaamsafmetingen geweest zijn; zijn borst mat van tepel tot tepel 3 hasta (meer dan 1 Meter). Vandaar ook de naam Lebar Telapak; aan zijn groot en breed voetspoor was hij altijd te herkennen. Temenggoeng's urineloozing was zóó overvloedig, dat toen hij eens op een heuvel urineerde een rijstblok op het vocht wegdreef en het water een danau vormde (Danau Temenggoeng, \pm 3 K.M. van de tegenwoordige doesoen Loeboek Mahang gelegen). Hij huwde later Polot, een vrouw, die in lichamelijke afmetingen niet voor haar echtgenoot onderdeed. Deze vrouw was afkomstig van de doesoen Gemoeroeh, gelegen in de nabijheid van de doesoen Betoeng, marga Rimba Asem. Uit het huwelijk van deze lieden ontsproten zes ,gewone" zonen, te weten: Sedjaring = de vischvanger; Semintjam $=$ de dreiger, de moed; Semobah $=$ de verhuizer $;$ Sebaok $=$

1) Een analoog verhaal over den vorst van de Boelian-Koeboes Raden Nagasari wordt vermeld door G. J. van Dongen op blz. 301 van zijne verhandeling: „De Koeboes in de onderafdeeling Koeboestreken der residentie Palembang", in de Bijdr. Kon. Inst. dl. 63 (1910). Indien niet anders vermeld, betreffen de verdere verwijzingen naar Van Dongen deze verhandeling. 
de eerwaardige (met baard en onderkin) ; Senandang $=$ de handelaar; Semoeboeng $=$ de steun, medewerker.

Het is typeerend dat deze gegevens wat het verhaal van de herkomst van Temenggoeng en Polot betreft, in hoofdzaak overeenkomen met de desbetreffende mededeelingen van Van Dongen (de Koeboes in de onderafdeeling Koeboestreken 185 e.v.). Volgens Van Dongen echter zouden Temenggoeng en Polot zich in de Lalanstreek en bij de Bahar hébben opgehouden. Eerst na het verdwijnen van Temenggoeng en Polot zou de splitsing van de Koeboestam van uit Moeara Bahar hebben plaatsgevonden. Sedjaring, de zoon van Temenggoeng en Polot zou daarna naar Kelapa Banjak zijn getrokken. Hij zou te Soegi Waras (Moesi Ilir) een mooi meisje Retani hebben ontmoet. Samen trokken zij naar Kelapa Banjak, met medeneming van zeven rijstaren. De korrels van deze aren werden het eerst als zaaizaad gebruikt en sindsdien kennen de Koeboes het planten van rijst (Van Dongen, pag. 187 e.v.).

Later trok een gedeelte der Koeboes zuidwaarts; hierover deelt de pasirah van Koeboe Bajat het volgende mede: Temenggoeng (of zijn zoons?) werd door Sinom van Kelapa Sebatang als broeder aangenomen, waarop de grond verdeeld werd tusschen beide personen. De grens was de Kali Beraoe; Temenggoeng (of zijn nakomelingen?) kreeg het zuidelijk gedeelte (thans de marga Koeboe Toengkal Oeloe) en Sinom het Noordelijk gedeelte, thans de marga Koeboe Bajat. Temenggoeng's volgelingen vestigden zich te Moeara Simpang ( \pm 5 K.M. van de huidige pasirahdoesoen Meranti Pandjang gelegen). Vandaar trok men naar Talang Boeroek, Tjengal en Meranti Pandjang. De eerste woonplaats tijdens het Sultansbestuur van den gindè van Bajat (dorpshoofd of ladanghoofd) was Tampang. De eerste gindè van Koeboe Toengkal woonde te Moeara Simpang. Deze gindè's werden door de Sutans als pasirah aangesteld.

Het Gouvernement erkende den pasirah van de marga Koeboe Bajat te Tampang, den grootvader van den tegenwoordigen pasirah, pangeran Oesman, genaamd Adjat. Spoedig daarna werd de pasirahstandplaats verlegd naar Locbock Mahang. Omstreeks 1920 verhuisde de tegenwoordige pasirah naar Pangkalan Bajat. Ten Oosten van Pangkalan Bajat op \pm 1 K.M. afstand is nog een graf te zien van een der afstammelingen van Sinom, genaamd Djelarah. Hieruit kan dus worden geconcludeerd dat de bewoners van Koeboe Toengkal afkomstig zijn van Koeboe Bajat. Van belang is echter de mededee- 
ling van den gewezen Krio van de doesoen Sakokarangan, Adim bin Retawin. ${ }^{1}$ ) Deze oude man, hoewel reeds \pm 75 jaar oud, is nog levendig van geest en weet zich de verschillende lotgevallen en verhalen van zijn geslacht nog goed te herinneren. Zijn grootvader was een Koeboe, afkomstig van Tandjoeng Karoeng, destijds gelegen aan de samenvloeiing van de Toengkal- en Dawasrivier, omtrent 60 K.M. van Sakokarangan verwijderd.

Deze grootvader, Lepak genaamd, stichtte de oude kampoeng Sakokarangan en werd daar Depati (dorpshoofd) omstreeks 125 jaar geleden. Gelijkertijd werd de doesoen Gersik gesticht. Evenals die van Gersik, zijn de inwoners van Daboek oorspronkelijk afkomstig van de oeloe toeloeng soengei Boeaja (bij de Toengkal rivier).

Vergelijkt men deze gegevens met het verhaal van de oorsprong van de marga Dawas (zie boven) dan vallen de volgende punten van overeenkomst op te merken: ${ }^{2}$ )

Als uitgangspunt wordt in beide streken genoemd de samenvloeiing van de Toengkal- en de Dawasrivier. De ,negeri” heette Tandjoeng Kerangan (Dawas) of Tandjoeng Karoeng (Sekokarangan). Vanuit deze nederzetting voer men de Dawasrivier stroomopwaarts, waar Karsoedi, de vreemdeling, zich vestigde. De naam van den radja (het hoofd) der nederzetting Tandjoeng Kerangan is in Dawas niet (meer?) bekend. In Sakokarangan wordt genoemd Lepak (zoo niet de radja van Tandjoeng Kerangan, dan toch een hoofdman, die een nieuwe nederzetting stichtte). De naam van Karsoedi komt ook voor

1) Van Dongen (op pagina 242) noemt als hoofdmalim (Malim pengasoe) van de Toengkal Koeboes Ertazwin te Sakokarangan. Dit is de vader van genoemden Adim.

2) Dit verhaal, in de memorie $17 \mathrm{blzz}$. tevoren opgenomen, luidt als volgt:

In vroeger tijden moet aan de samenstrooming van de Toengkal- en de Dawasrivier een nederzetting geweest zijn (de pasirah noemt het een negerie), genaamd Tandjoeng Kerangan. De naam van het hoofd dezer nederzetting (de radja) is niet bekend, doch zijn broer (of aangenomen broer) heette Karsoedi. Men leefde rustig bijeen, totdat de nederzetting werd verwoest door een leger van het rijk Boernai(?). (Op mijn vraag of Boernai misschien identiek is met Borneo, werd door den pasirah ontkennend geantwoord; de lieden van Boernai zouden van de Bovenlanden van Palembang afkomstig zijn). De dochter van den vorst van Tandjoeng Kerangan heette Poeteri Majang Mengoerai, zij werd opgevoed door haar oom Karsoedi. Poeteri Majang Mengoerai was zeer mooi, zoodat vele jongelieden moeite deden om haar tot vrouw te krijgen. $\mathrm{Zij}$ weigerde echter steeds. Op zekeren dag verscheen de jonge prins Poetera Mahkota van Boernai met een zeer talrijk gevolg om de prinses, wier schoonheid wijd en zijd beroemd was, ten huwelijk te vragen. De prinses weigerde echter, ondanks herhaald aandringen van Poetera Mahkota, op zijn voorstel in te gaan. 
in Bajat, waar deze vreemdeling den Koeboes het nut van klappers zou hebben doen kennen (zie boven).

Hieruit kan zonder bezwaar worden geconcludeerd, dat de nederzetting aan de samenvloeiing van de Dawas- en Toengkalrivier uit Koeboes heeft bestaan. Blijkens het verhaal van Dawas zijn deze oorspronkelijke bewoners verdreven door Maleische (?) stammen uit het binnenland. De lieden van Dawas en Koeboe Toengkal zouden dus ten deele een gemeenschappelijke afstamming hebben. Het is mogelijk dat dit in Dawas ontkend wordt uit schaamte. Toch heeft de ontwikkeling van Dawas, mede door vestiging van talrijke vreemdelingen, zoo'n voorsprong behaald, dat ik het verantwoord achtte laatstgenoemde marga niet meer tot de groep der Koeboemarga's te rekenen. Of de Koeboes van Tandjoeng Kerangan eenzelfde oorsprong hebben als die van de oeloe Kepahiang (Lalan) is niet na te gaan; de mogelijkheid bestaat dat verbinding te land (van Mangsang naar Gersik) heeft bestaan. In elk geval bestaat de herinnering aan een gemeenschappelijke afstamming niet meer.

Over de Koeboes in de marga Pinggap worde nog het volgende medegedeeld: Ongeveer 100 jaar geleden hadden deze Koeboes nog geen vaste woonplaats en zwierven door de uitgestrekte bosschen in het noorden van deze marga. Vanwaar deze Koeboes afkomstig waren wist men mij niet te zeggen. Volgens Van Dongen (pagina 188) zou een gedeelte van de lieden van Kelapa Banjak (zie boven) naar de Dangkoerivier, een zijrivier van de Batang Hari Leko, zijn verhuisd,

Hierdoor ontstond een jaren-lange strijd, waarbij Poetera Mahkota een reusachtig leger zou hebben aangevoerd. Dit leger was zóó groot, dat indien de voorste rij (tien soldaten per rij) djagoeng plantte, dan kon deze djagoeng door de middelste rij van het leger reeds worden gegeten. Dit fantastisch leger was dus acht maanden lang. Eindelijk vluchtte de vorst van Tandjoeng Kerangan. De prinses verdween plotseling van deze aarde. Karsoedi trok de Dawas rivier stroomopwaarts totdat hij kwam aan een plaats, waar hij een ladang wilde aanleggen en te dien einde een verbodsteeken plaatste (terawas). Hier is de doesoen Dawas gesticht. In het museum van Palembang zou nog een kris van Karsoedi zijn welke, indien men daarover heen stapt, onheil veroorzaakt. Aan de monding van de Dawas in de Toengkal-rivier is nog een „tjandi" te zien; deze tjandi is echter slechts een verwaarloosd graf, waar de bevolking nog steeds heen trekt om zegen en hulp van de voorouders af te smeken. Later zijn vele personen van Palembang (het tegenwoordig pasirahgeslacht), Loempatan, Komering Oeloe enz. zich te Dawas gaan vestigen. Tijdens het Nederlandsch Bestuur zijn vele Koeboes, afkomstig van Daboek (Koeboe Toengkal Oeloe) Dawas binnengedrongen en hebben zich geleidelijk op het talanggebied van die marga gevestigd. Eenige band bestaat met de marga's Soepat en Pinggap door huwelijken en verhuizing. 
om daar de doesoen Ikan Lèbar te stichten. Het is mogelijk dat een gedeelte dezer lieden zich heeft opgehouden in de bosschen tusschen de Soengei Dangkoe en de Soengei Rampasan (beide zijrivieren van de Batang Hari Leko). Hoe dit ook zij, de rondzwervende lieden stichtten onder aanvoering van hun hoofd Renato de doesoen Laman Soelai; zij trokken daarna steeds meer Westwaarts en stichtten achtereenvolgens van Oost naar West: Talang Medang Besar, Talang Boeloeh en de thans nog bestaande Talang Medang Tjelèngkong. Het jachtgebied van deze stam strekte zich uit tot de Soengei Dangkoe ten Noorden, de Soengei Rampasan ten Zuiden, ten Westen de Batang Hari Leko en ten Oosten de waterscheiding tusschen de Batang Hari Leko en de Lalanrivier.

Het territoir der Laman Soelai Koeboes was vroeger vrij streng afgesloten voor andere Koeboestammen. Deze mochten niet op hun gebied jagen, visschen en boschproducten verzamelen dan met toestemming der oudsten. De verzamelaar moest een gedeelte van de opbrengst aan alle ingezetenen afstaan; de hoofden kregen niet meer dan de andere stamleden. Overtreding van het occupatie-verbod werd vrij streng gestraft, zelfs verwonding en doodslag kon hiervan het gevolg zijn. Het waken tegen inbreuk op deze rechten, moet gezien worden als een economische noodzaak. Hetgene dat men voor zijn levensbehoefte noodig had, was betrekkelijk zoo spaarzaam te verkrijgen, dat een uitgestrekt jacht- en verzamelterritoir een eerste levensvoorwaarde voor deze Koeboes was. ${ }^{1}$ )

De Koeboes van Batang Hari Leko (vroeger genoemd Koeboe Oeloe Leko), zijn zooals boven reeds werd medegedeeld, afkomstig van Ikan Lebar. De vóór-vorige pasirah van de marga Koeboe Oeloe Leko woonde nog te Ikan Lebar. Tijdens den bekenden Controleur Van Dongen is de oorspronkelijke nederzetting naar de Batang Hari Leko verhuisd en werd Pangkalan Boelian gesticht, thans nog de pasirahdoesoen. Deze Koeboes zijn oorspronkelijk afkomstig van Kelapa Sebatang (zie Van Dongen, pagina 188). Aan de boven Batang Hari Leko zouden zich ook Koeboes van de Kloempangrivier (Rawas) hebben gevestigd (Van Dongen, pag. 189).

1) Vide ook „De Palembangsche marga” van J. W. van Royen op pag. 120: „Het is duidelijk dat een dergelijke wijze van kostwinning een geweldige oppervlakte gronds eischt..... Botsing met andere groepen legt langzamerhand de grenzen van het gebied vast. Het geheele gebied is productiemiddel. Buitenstaanders daarin toe te laten is, op straffe van voedselgebrek, niet geoorloofd". 


\section{b. Gewoonten en gebruiken der Koeboes.}

Kleeding: In de bosschen is de schaamgordel van boombast (tjawat) voor mannen zoowel als vrouwen de eenige lichaamsbedekking. In de doesoen heeft men kains en baadjes terwijl zelfs pyama's reeds worden gedragen. Versierselen worden gedragen door kinderen en jonge meisjes (enkelringen en armbanden, oorknoppen, enz.). Alle in deze onderafdeeling levende Koeboes zijn geregistreerd. Wel zwerven soms van Djambi afkomstige Koeboes in de streken langs de Lalanrivier rond en houden zich daar eenigen tijd op, doch vroeger of later verdwijnen zij weer. De Koeboes dezer onderafdeeling hebben allen een doesoen of talang tot min of meer permanente woonplaats, vanwaar zij voor korter of langer tijd geregeld uitzwermen om in de bosschen producten te zamelen en te jagen.

De Islam: De inwoners van Koeboe Bajat en Koeboe Toengkal Oeloe, en Dawas zijn vrijwel geheel tot den Mohammedaanschen godsdienst overgegaan. Dat deze overgang in het bestaan van deze lieden veel heeft gewijzigd kan worden ontkend. In de doesoen verzet het schaamtegevoel zich tegen het nuttigen van allerlei verboden spijs. In de bosschen stoort men zich aan de voorschriften vaak niet. In een ander verband $\mathrm{zal}$ nog worden aangetoond dat tal van heidensche gebruiken en voorstellingen zich binnen het kader van den Islam gehandhaafd hebben. In de marga Koeboe Lalan bestaat ongeveer de helft der bevolking nog uit Koeboes, die niet tot den Islam zijn overgegaan. Van de 51 heerendienstplichtigen der doesoen Mangsang zijn b.v. 27 nog heidenen. De overige personen zijn afkomstig van Palembang, Komering Oeloe en Ogan Ilir.

Woonzrijze: In de doesoens der Koeboestreken treft men veelal zeer primitieve woningen aan. Aan de rivieren of op de talangs staan tijdelijke hutjes, enkele meters lang en ongeveer een meter hoog, ongeveer $1 \frac{1}{2}$ Meter boven den grond. Als dakbedekking dient kadjang. De wanden, voor zoover die aangebracht zijn, bestaan uit kadjang, het geheel steunt op dunne, onbewerkte houtstammen. De oorspronkelijke woon- of liever schuil- en slaapplaatsen waren nog primitiever. De daken dier hutten waren opgetrokken van lipai-bladeren, één zijde raakte den grond en de andere zijde werd geschraagd door ruwe houten palen of stammen. Deze hutten hadden dus de vorm van een tent. Deze vorm heette ,andjing beroeang”, aangezien zij leek op de geopende bek van een hond, wanneer deze 's avonds tegen de maan blaft of huilt. 
Bestaansmiddelen: Men leeft van de verbouw van oebi, pisang, suikerriet, vischvangst en jacht en het verzamelen van boschproducten. Soms legt men zich ook toe op het planten van rijst op ladangs.

Voedsel: Dit bestaat uit: 1. rijst, oebi, banoer (e.s.v. wilde oebi), suikerriet, pisang, sekoesoet, bahai en koena (alle knolvruchten); 2. schildpad, leguaan, stinkdas (koekoes of telegoe), nangoei (het baardzwijn), wilde varkens, tapir, badjing, visch en verschillende hertsoorten. Slangen worden ook wel genuttigd.

Wapens: Speer, kris en parang. De speer (koedjoer brongsong) wordt zelf vervaardigd. De ijzeren punten worden veelal gemaakt van gevonden materiaal van verlaten boorterreinen en pijpleidingen. De vaardigheid in het speerwerpen is groot. Op 8 meter afstand kan men een rotanstengel klieven.

Baden en reinigen: De Koeboes die langs de rivieren wonen, baden zich geregeld. In het bosch wordt dit (soms noodgedwongen) veelal achterwege gelaten. Hier reinigt men zich, na zijn gevoeg te hebben gedaan, vaak door zich van achteren aan een tak of boompje schoon te schuren.

Zwangerschap en geboorte: Over deze onderwerpen handelt Van Dongen uitvoerig (pag. 228 e.v.); slechts zij aangeteekend, dat het zich verwijderen van de vrouw van haar huis kort vóór de bevalling, v.z.v. bekend, thans niet meer voorkomt. Ter vergemakkelijking van de bevalling worden kisten en deuren enz. geopend. (Zie voor dit onderwerp verder $\S g$, ziekteleer).

Huwelijk: Er wordt een bijeenkomst belegd van familieoudsten, waarbij de voorwaarden, welke bij de huwelijkssluiting in acht genomen dienen te worden, vastgesteld worden. $\mathrm{Zijn}$ de wederzijdsche familieleden, en ook de jongelieden het eens, dan staat geen beletsel het huwelijk meer in den weg. Vaak wordt door den vader van het meisje bedongen een bruidschat van f 20.- tot f 50.-, welke in termijnen mag worden voldaan en ook in natura (boschproducten) kan worden opgebracht.

Denzelfden dag (van de bijeenkomst) wordt het huwelijk voltrokken, op de volgende wijze. De aanstaande echtgenooten zitten naast elkaar, te midden der familieleden. $\mathrm{Zij}$ worden in het gezicht, op de schouders en op de plaats waar de lever zich bevindt met rijstemeel bestreken om aldus van onreinheid (onheilen) te worden gezuiverd. Dẹ bruid draagt bij deze gelegenhẹid oorknoppen. 
De moeder van de bruid begint hierop de volgende pantoen te zingen :

„Pisang kelat, pisang tembatoe

„Goegoer moembang, kelapa tjina.

„Soedah penat tangan memangkoe

„Tjaboet soebang dari telinga". ${ }^{1}$ )

Hierna neemt de bruidegom de oorknoppen uit de oorschelpen van zijn bruid als teeken dat zij voortaan geen magd meer is. De moeder van den bruidegom antwoordt heirop als volgt:

„Roemah ketjil tiang seriboe

„Roemah besar dimakan api.

„Lagi ketjil dipangkoe iboe

„Soedah besar dipangkoe laki."

(vide ook Van Dongen, pag. 220).

De door Van Dongen aangehaalde pantoen van de bruid en die van den bruidegom (zie pag. 220) worden in Koeboe Lalan niet meer gebezigd.

Huwelijken van Koeboemeisjes met Maleisch-Mohammedaansche mannen komen wel voor. De aanstaande echtgenoot moet dan aan den vader van het meisje een bedrag ad \pm f 30 . - betalen, genaamd ,teboes nangoei”. Het meisje mag namelijk nà haar huwelijk met een Mohammedaanschen echtgenoot uiteraard geen nangoei meer eten. Thans kan ook met een minder bedrag worden volstaan. De vrouw volgt haar man in den regel onmiddellijk naar diens verblijfplaats.

Huzvelijksbeletselen. Het huwelijk is verboden tusschen personen, die elkaar bestaan tot en met den tweeden graad. Leviraatshuwelijk komt wel voor; verplicht is dit echter niet. Het huwelijk met een stiefbroer of -zuster en met een oom of tante is verboden.

Overlijden. Vroeger bouwde men voor overleden personen een stellage, voorzien van een afdak en een trap. Het lijk werd dan in een kain gewikkeld en door een soort klamboe, of wat daarvoor moest doorgaan, omgeven. De nederzetting werd daarna door de overlevenden verlaten. Dit wegtrekken werd genoemd melangoen (d.w.z. het verdriet ontvluchten) of lorot (= lari). Thans worden de lijken begraven met het hoofd naar het Westen gekeerd. Op het graf worden, aan het hoofdeinde pisangs en oebi benevens strootjes gelegd. De(n)

1) Moembang $=$ een onvoldragen klappervruchtje; Penat $=$ vermoeid. 
doode wordt daarop verzocht, te zwijgen (djangan tegoer). De bedoeling is dus de(n) doode tevreden te stellen, door het verschaffen van de noodige mondvoorraad en hem (haar) zoodoende niet in de verleiding te brengen de nabestaanden door zijn (haar) terugkeer te verontrusten.

$\mathrm{Bij}$ het graf der dooden wordt vaak om hulp gevraagd bij te ondernemen tochten, genezing van een kind afgesmeekt enz. Bij het graf van Djelarah, een voorvader der Koeboes te Pangkalan Bajat werd door mij b.v. het volgende aangetroffen. Aanwezig was een kommetje om mennjan (benzoë-hars) te branden en houten stokjes, welke \pm 1 span lang zijn. Wordt een verzoek der nazaten b.v. tot genezing van een kind, ingewilligd, dan verbeeldt men zich dat de stokjes langer zijn geworden. Blijft de lengte gelijk, of wordt deze kleiner, dan is de uitslag twijfelachtig. Men spreekt hierbij de volgende woorden uit: „Moening (voorvader) kalau saja poenja anak semboeh dalam tempo „3 boelan, nanti saja potong kambing”.

\section{c. Vooroudervereering en de invloed daarvan op het gedachten- leven.}

Wanneer men een feestmaal aanricht wordt in het huis een vuurtje gestookt. De gastheer gooit daarbij stukjes mennjan in het vuur onder het uitspreken van de volgende woorden: „Salam alaikoem, salam, „satoe, doea, tiga, empat, lima enam, toedjoeh, kamoe melaikat „pojang, kamoe melaikat bapô (vader), kamoe melaikat mé (moeder), „pajo, makan minoem kamoe. Kami nio (ini) sedekah. Kami nio „baroe soedah noeai (oogsten). Djangan kamoe keponan (tjelaka), „makan padi baroe”. De bedoeling is dus, de voorouders door het verstrekken van pas geoogste rijst gunstig en vergevensgezind te stemmen, opdat den levenden geen onheil geschiede.

Aan kinderen, die vechten of kibbelen wordt de waarschuwing gegeven: „djangan kamoe belégé, nanti melaikat nenek marah”. Een uitroep van dezelfde strekking is: „djangan bernéko (= elkaar plagen), nanti ditegoer antoe nenek".

\section{d. Beschikkingsrecht over den grond.}

Het beschikkingsrecht behoorde vroeger tot de gemeenschap. Een Koeboestam heeft een zeer groot territoir noodig om in de levensbehoeften der leden te kunnen voorzien. Tegen inbreuken op het beschikkingsrecht door vreemdelingen werd mitsdien streng gewaakt. 
Dezen mochten niet op het territoir jagen, visschen en boschproducten verzamelen, dan met toestemming der oudsten. De niet tot de gemeenschap behoorende jager of verzamelaar moest een gedeelte van de opbrengst aan alle leden der gemeenschap afstaan; dit gedeelte werd gelijkelijk onder deze genooten verdeeld. Bij overtreding van het verbodsvoorschrift werd de schuldige door den depati en de oudsten veroordeeld tot betaling van ten hoogste 20 geloeng rotan, 20 boengkoes mennjan of 20 piring kerang (ruw aardewerk, schotels of borden van Palembang afkomstig). De minimumstraf was 5 geloeng rotan of 5 boengkoes mennjan of 5 schotels.

\section{e. Rechtspleging.}

Naleving van de opgelegde boete had meestal vrijwillig plaats. De veroordeelde moest het geeischte binnen 10 à 15 dagen leveren. Bleef hij in gebreke, dan had dit bloedige vechtpartijen tusschen de twee betrokken stammen tengevolge, waarbij men elkander met koedjoer brongsong of parang te lijf ging. Er werd zóólang gevochten tot er één of meer dooden gevallen waren, waarna de zaak als afgedaan beschouwd werd.

Werd een lid van een naburige stam ervan verdacht een overtreding te hebben begaan op het territoir van de gemeenschap en ontkende deze persoon, dan werd de ,waterproef" toegepast, welke hierin bestond, dat de verdachte onder water moest duiken en zoo lang mogelijk onderblijven. Beschikte hij over veel uithoudingsvermogen, dan werd die persoon onschuldig verklaard. Kwam hij naar den zin zijner rechters te vlug boven water, dan werd plechtig het schuldig over hem uitgesproken. In andere gevallen werd den verdachte een eed opgelegd welke op de volgende wijze werd uitgezworen. De hoofden steken een stukje mennjan aan; de verdachte raakt met zijn hand de mennjan aan en spreekt de volgende woorden: „kalau kaoe salah, kepoetjoek tidak njoeroeng poetjoek, kebawah „tidak njoeroeng bangkar (akar), 'mba roempoet ditengah djalan, ,'mba aboe dipoetjoek boeboengan" (de z.g. soempah boemi)". ${ }^{1}$ ) De bedoeling is dus: Wanneer jij (ik) een valsche eed zweert, ben je tot niets nut, zooals gras op den weg en asch op het dak.

Voor sancties, welke op andere delicten gesteld zijn of waren, worde verwezen naar Van Dongen, a.w. blz. 291 v. Ik teeken daarbii aan dat het Bestuur van eventueele adatdelicten der Koeboes zeer

1) ${ }^{\prime} m b a=$ seperti; bangkar $=$ akar. 
zelden kennis krijgt. Zoo mogelijk wordt het vergrijp onder elkaar besproken en goedgemaakt door betaling van de boete.

\section{f. Gebruiken bij aanleg van rijstvelden en tuinen.}

Een stuk grond in het oerwoud wordt schoongemaakt; in het midden wordt een stuk pelangas-hout van \pm 1 depa lengte gelegd en met mennjan bestreken, waarna de volgende woorden worden uitgesproken :

1. Oh, Tergoeroe toedjoeh toenggoe dihoetan,

2. Anak Tergoeroe toedjoeh toenggoe doesoen,

3. 'Ndak minta boeat ladang sawah,

4. 'Ndak nanam temiang berseri koening,

5. Djikalau akoe boleh meminta' tanah,

6. Dari kamoe poenja ternak ingonan,

7. Bawa poelang dirimba jang lain,

8. Esok kalau tjapô soedah toemboeh dipoetjoek toenggák,

9. Mengerti kami soedah moendoer dari tanah ini,

10. Kamoe baliklah dikamoe poenja tanah,

11. Kalau kajoe ini ésok pandjang,

12. Artinja boleh; kalau tidak boleh minta djadi pendek. ${ }^{1}$ )

Aan de „Tergoeroe toedjoeh” wordt dus vergunning gevraagd het bosch te occupeeren en een ladang te maken.

De bedoeling van regel $7 \mathrm{t} / \mathrm{m} 10$ is dat de ladangbouwer belooft de grond terug te geven wanneer deze is afgeoogst (wanneer de bloekar weer is opgeschoten). In de regels 11 en 12 wordt de „Tergoeroe toedjoeh" om een teeken gevraagd; wordt het verzoek ingewilligd, dan blijkt dit uit het feit, dat het stuk pelangashout langer wordt. Is het korter geworden, dan wordt de grond verlaten, aangezien de Tergoeroe toedjoeh blijkbaar hiertegen bezwaren hebben.

$\mathrm{Na}$ de oogst wordt ten huize van den ladangbezitter een sedekah aangericht. De Tergoeroe toedjoeh worden onder het aanbieden van voedsel als volgt aangesproken:

$$
\begin{aligned}
& \text { „Ini akoe poenja padi djadi. } \\
& \text { „Ini akoe sedekah. }
\end{aligned}
$$

1) Temiang $=$ kleine bamboe. Temiang berseri koening $=$ dichterlijke omschrijving van padi. Ternak ingonan = peliharaan, dwz. alles wat tot de „Tergoeroe toedjoeh" behoort, dus eventueele (booze) geesten, die over de ladang cnheil zouden kunnen brengen. Tjapò $=$ bloekarhout. Esok $=$ later. Toenggak $=$ stronk. 
„Djadi makan minoem oleh kamoe.

„Jang mana mamboe baik rasô.

„Lepas kamoe makan minoem.

„Kami makan minoem soepaja berkat”.

De Tergoeroe toedjoeh zijn de 7 geesten, die als beschikkers over den grond en alles wat daarop groeit, worden erkend.

Bij de ladangwerkzaamheden, is het geheele gezin in een kleine pondok aan den rand van het rijstveld verzameld. Bij het nebas en nebang wordt de gambang bespeeld (zie beneden onder het hoofd muziek en zang). Vermoedelijk heeft de bespeling van de gambang een magische bedoeling (gehad). Moet hierbij gedacht worden aan een vruchtbaarheidsrite? Hiervoor pleiten m.i. twee omstandigheden: 1. de vrourw bespeelt de gambang; 2 . bespeling heeft plaats op het te beplanten rijstveld.

\section{g. De ziekteleer.}

De hieronder volgende gegevens zijn afkomstig van de Koeboes van de doesoen Mangsang (Koeboe Lalan). De dorpsheelmeester en bezweerder heet Alitjik bin Ta' Alam. Zijn grootvader, genaamd Seniat, oefende reeds dezelfde functie uit. Aanvullende gegevens werden verkregen te Meranti Pandjang, hoofdzakelijk van den Malim Rais bin Aliitam. De voorstelling dezer personen is doorvlochten met allerlei Mohammedaansche denkbeelden en uitdrukkingen. Overigens zijn deze geheel heidensch.

1). Toen Nabi-Adam uit de 4 elementen werd geformeerd, te weten aarde, water, lucht en vuur, ontstonden door de samenvoeging dier tegengestelde elementen verschillende geesten, die ziekten of onheilen veroorzaken. De geest die naar de lucht vloog was Bala Beroeang. Deze geest doet de ziekte van enkelingen ontstaan; vooral is hij de oorzaak van plotselinge ziekten of sterfgevallen (onverwacht sterfgeval, verlamming, enz.). De geest die uit het water ontstond wordt genoemd Radèn Koening of Orang di Laoet. Radèn Koening doet epidemiëen ontstaan (cholera, pokken). Een andere geest is Adam Moengkim (de aardgeest), die de ziekten doet ontstaan, welke, naar men zegt, met de aarde in verband staan. Heeft b.v. iemand een ladang aangelegd en krijgt hij daarna voortdurend koorts, dan is deze ziekte door toedoen van Adam Moengkim ontstaan. Ook wordt hij wel genoemd Sètan di tanah. Al deze ziekten worden dus gedacht 
veroorzaakt te zijn door toedoen van booze geesten, welke bezworen moeten worden.

2). Een andere categorie van ziekten ontstaat uit het lichaam zelf, zooals uitslag, framboesia, schurft, enz. Middelen hiertegen zijn zwavel, rijstemeel en helsche steen.

3) Weer andere ziekten ontstaan door het afdwalen van de soemangat. Het afweermiddel hiertegen is berdikir (bermalim) of bersalèh.

$\mathrm{Bij}$ bezwering van ziekten, door Bala Beroeang veroorzaakt, gaat men als volgt te werk.

Deze ziekten worden genoemd tangkapan (een mensch wordt dus als het ware door Bala Beroeang uit de lucht overvallen). Een platvorm van bamboevlechtwerk, 80 c.M. in het vierkant, wordt aan het boveneinde van een 5 meter lange bamboepaal bevestigd. Het platform wordt bedekt met pisangbladeren. Hierop wordt een takir (bekertje) van pisangbladeren geplaatst, waarin zich een papje van rijstemeel bevindt. Voorts wordt een poendjoeng met zwarte ketan, een zwarte kip, zwart suikerriet, zwarte oebi, melati, selasih, tjendana, 3 gevulde nipahstrootjes, 3 bereide sirihpruimen en klapperolie op het platform aangebracht. In de klapperolie worden de uiteinden van een kajoe bangoen stokje gedoopt. Aan de 4 zijden van het platform wordt gepofte rijst aan een draad geregen waarop deze versiering aan de 4 hoeken wordt opgehangen. Tevens worden aan de hoeken kaarsen (dian) aangestoken.

De sanggar, d.w.z. het platform met de 5 meter lange bamboestaak, wordt buiten het huis van de zieke opgesteld; een lijn van nilanbast wordt van de sanggar naar het huis van de patiënt gelegd, die deze lijn met zijn (haar) hand vasthoudt. Deze lijn, welke malai wordt genoemd, is versierd met pisangbladeren, selasih enz., terwijl op ongeveer een spanwijdte van de patiënt een zilveren ring wordt ingeknoopt. De bezwering geschiedt dan als volgt:

De doekoen steekt 's avonds de kaarsen aan, hij loopt eerst van links naar rechts om de sanggar heen, totdat de kaarsen zijn opgebrand. De echtgenoote van den doekoen vergezelt haar man daarbij. Af en toe valt de doekoen in onmacht, waarbij de omstanders hem dan vasthouden. De doekoen roept de ziektegeest als volgt aan:

„Ini antar roebo pe'sembah pada kamoe.

„Melainkan saja minta' ini orang soepaja waras. 
„Kalau kamoe jang menjakiti dan menjiksa, saja minta' ampoen ,ini orang. Soedah kamoe memakan dan minoem, saja minta' ting"gali obat dan djampi; jang tadjam saja minta toempoel, jang bisa ,saja minta' tawar". ${ }^{1}$ )

Hierna worden de bezweringsmiddelen (selasih, tjendana, geurige olie enz.) naar het huis van de zieke gebracht.

Wanneer de doekoen de trap van het huis betreedt, vraagt hij met luiderstem : „Apa kabar si-.....” (de naam van de patiënt), hierop wordt vanuit het huis geantwoord: „Soedah baik, soedah berdjalan, „soedah mantjing, makan, minoem”. Hierna treedt de doekoen binnen en besprenkelt de patiënt met selasihwater en rijstemeel, welke ingrediënten hij met een kajoe bangoen stokje op het lichaam van de patiënt aanbrengt. Daarna vertrekt de doekoen.

Beneden aangeland, leunt hij tegen de sanggar aan en valt in zwijm (trance). Men houdt hem vast en geeft hem wierook te ademen; zijn echtgenoote roept hem op hooge, schelle toon tot het bewustzijn terug (pantau soemangat), waarna de doekoen weer bijkomt. Terwijl de doekoen in trance is, wordt de verbindingslijn van de sanggar met de patiënt afgesneden bij de plaats waar de zilveren ring is bevestigd. Het einde van deze lijn wordt met de zilveren ring aan de rechterpols van de patiënt bevestigd, totdat deze geheel genezen is. De sanggar met inhoud wordt weggegooid of vernietigd. De bedoeling van deze bezweringshandelingen is m.i. duidelijk. De groote hoogte van de sanggar (5 M.) dient natuurlijk om de geest van de lucht of wolken (Bala Beroeang) gemakkelijk te bereiken.

$\mathrm{Bij}$ het bezweren van epidemië̈n, veroorzaakt door Radèn Koening, worden dezelfde handelingen toegepast. De sanggar is dan echter slechts 1 tot $1,50 \mathrm{M}$. hoog, terwijl alle ingrediënten in plaats van zwart, geel zijn. Bij bestrijding van ziekten, ontstaan door Sétan di tanah, zijn de benoodigde ingrediënten wit.

Bij bestrijding van ziekten, welke uit het lichaam ontstaan, beperkt de doekoen zich tot het aanbrengen van geneesmiddelen (zwavel, helsche steen, enz.), waarbij hij eenige spretıken mompelt.

Bij het beschrijven van de bezwering van ziekten, welke door afdwaling van den geest zijn veroorzaakt, dienen in de eerste plaats vermeld te worden het bermalim of berdikir en het bersalèh.

1) djampi $=$ tooverspreuk, toovermiddel; bisa $=$ vergift $;$ tawar $=$ verzachten, neutraliseeren. 
Beide wijzen van bezwering, of liever van het verkrijgen van contact met den geest van den zieke door middel van het medium, malim (bij bermalim of berdikir) of den Sidi (bij bersalèh), geschieden door den doekoen als bemiddelaar tusschen de geestenwereld en de menschen (sjamanisme). Het verschil tusschen bermalim (berdikir) en bersaleh bestaat hierin, dat de Sidi (bij het bersaleh) zich goed bewust is van hetgeen om hem heen geschiedt. Hij is ook vrijer in zijn keus van volgorde der verschillende salehs (heil- of zegenspreuken), waarvan in totaal 33 gebezigd worden. Bij het bersaleh moet de verlichting goed zijn; gaat een kaars of flambouw uit, dan moet fluks een andere worden aangestoken, aangezien anders de aangeroepen geest zich plotseling aan het lichaam en de invloed van den Sidi zou onttrekken. Bij het bermalim daarentegen is de verlichting zeer schaars, zelfs bij volle maan ontbreekt deze vrijwel geheel. De malim houdt zich meer afgesloten van zijn omgeving; hij is daardoor ook streng gebonden aan de vaste volgorde der 33 salehs.

Men onderscheidt verschillende soorten van bermalim en bersaleh. Slechts de voornaamste mogen hieronder vermeld worden .

\section{B e r ma $1 \mathrm{im}$.}

1. Beringin ketjil. Deze soort van bermalim wordt toegepast bij bezwering van ziekten (het terugroepen van de afgedoolde geest). Hierbij wordt een beringin tiga pangkat gebruikt. Dit instrument bestaat uit een bamboestok van \pm 35 c.M. lengte, met een sluitstuk aan den bovenkant van kajoebangoen (de kepala beringin). De kapala beringin wordt van bangoen-hout gemaakt, vermoedelijk om hiermede een overdrachtelijke beteekenis van bangoen $=$ opstaan, verrijzen van de ziekte, aan te geven. De onderkant van de beringin bestaat uit een vierkant vlak, gevormd door bamboelatjes. De opstaande, naar boven schuin toeloopende steunlatten, zijn aan de bovenkant verbonden door een kleiner vierkant van bamboe-latjes, terwijl in het midden van de beringin eveneens een vierkant steunvlak horizontaal is aangebracht. Het geheel heeft dus den, vorm van een afgeknotte piramide. Ter weerszijden is dit toestel versierd met rotanbladeren. Onder de beringin worden geregeld lekkernijen geplaatst, die na korten tijd weer worden weggenomen.

Het berdikir (bermalim) geschiedt door den malim in de balai, bijgestaan door de hoeloebalang (zijn echtgenoote) en de redabspeler (de bidoean). 
De malim doopt een tjendanatak (geurig kruid) in een schoteltje water en sprenkelt dit vocht daarmede op de patiënt en de beringin. De malim loopt dansend in een kring rond, af en toe gevolgd door schreeuwende en stampende omstanders (berêntak). Af en toe valt de malim in trance, waarbij hij door de omstanders gesteund wordt. De hoeloebalang roept hem op hooge schelle toon in het oor, waarna de malim ontwaakt. Hierna strijkt de malim de patiënt over het hoofd. De beringin wordt tijdens het berêntak beurtelings omhoog geheschen en gevierd; een soort van waskaars wordt daarbij aangestoken. Gaat de malim zitten dan blaast hij de kaars uit. Na afloop van de ceremonie wordt de beringin weggegooid.

Waarom het instrument dat gebezigd wordt beringin heet, is niet met zekerheid te zeggen. De malim van Meranti Pandjang (Koeboe Toengkal Oeloe) verklaarde mij, dat dit een waringin, een heilige boom, voorstelt. Het beringin ketjil of beringin tiga pangkat heet ook wel beringin perobatan. Deze ceremonie duurt één avond.

2. Verder wordt nog gebezigd het beringin moedjoek, welke wordt toegepast wanneer iemand reeds genezen is en men hem in het vervolg van allerlei ziekten wil vrijwaren (moedjoek $=$ boedjoek $=$ overreden, overhalen). Het beringin moedjoek duurt drie avonden en nachten. De eerste avond = ngegar balai; de tweede avond = gawé laboe; de derde avond $=$ ngoelang roenoet. Ngegar balai $=$ schudden van de balai, $=$ onderzoeken van de ziekte; gawé laboe $=$ het bezweren (het geven van geneesmiddelen); ngoelang roenoet $=$ de patiënt in de vroegere toestand van gezondheid terugbrengen.

3. Het beringin toedjoeh pangkat wordt bij ernstige ziekten toegepast. Hierbij wordt een beringin met 7 horizontale steunvlakken gebruikt.

$\mathrm{B}$ e r s a lè h.

De doekoen heet Sidi en zijn vrouw Inang. Men kent twee soorten bersaleh, te weten het bersaleh berobat en bersaleh moedjoek, d.w.z. het bersaleh om te genezen en het bersaleh om de(n) genezene voor verdere ziekten te behoeden. Bij het bersaleh wordt een balai of huisje uit het merg van een salakboom gemaakt ( \pm 40 c.M. lang en breed), waarin allerlei ingrediënten worden gelegd. Het huisje of de balai wordt aan 4 touwtjes opgehangen, die aan het boveneinde aan elkaar zijn vastgeknoopt.

De zieke zit onder dit instrument, dat beurtelings wordt gevierd en geheschen. In het huisje of de balai wordt een kaars aangestoken.

D1. 99. 
De Sidi draagt een witte hoofddoek en een kain; zijn bovenlijf is ontbloot. Ter weerszijden en aan den achterkant van het hoofd hangen aan draden geregen, gepofte rijstkorrels tot aan de heupen. Hij draagt tevens een versierde malai (zie boven) om de hals en om het middel. De om de hals hangende malai wordt vaak heen en weer bewogen boven het hoofd van de patiënt. Vóórdat de Sidi in trance komt, plaatst hij de malai op het hoofd van de patiënt.

Tijdens het heen en weer bewegen van de malai spreekt de Sidi dansend de volgende woorden uit:

„Hai, boeang segalo bisai panas,

„Tinggal berendoen dengan dingin,

„Tadjam toempoel, bisa tawar”.

Hierna legt de Sidi de malai op het hoofd van de patiënt, waarop hij het bewustzijn verliest. $Z$ ijn vrouw (Inang) roept hem, door pantau soemangat (zie boven) weer tot het gewone leven terug. Hierop zegt de Sidi :

„Bismillah rohmani rohim!

„Kalau kau datang dirimbo rajo, kalau datang pematang pandjang, kalau balik pematang pandjang,

„Djangan mentjoba, anak Adam kasih Allah”.

„Kalau tjampak di laman,

„Djadi djin sapoe laman.

„Tjampak di laoet, djadi djin sapoe rantau.

„Djangan mentjoba anak Adam kasih Allah.

„Boekan akoe menawari, anak betara goeroe jang menawari”.

(De booze geest wordt dus onschadelijk gemaakt; valt de geest op het erf, dan wordt hij als bezem gebruikt, valt hij in het water, dan kan men ook met hem doen wat men wil, m.a.w. de geest heeft geen macht meer over de zieke).

Ook wel wordt de volgende spreuk uitgesproken:

„Seroeang djatoeh kelaoet, seroeang djatoeh keboemi.

„Djadi djin, djadi sètan, djadi hantoe, djadi balo (geest).

„Doea boelan njalang (djalan) ketigo, nemoeni djandji semajo kito. „Radèn Koening sepanah alam, kaoe moedik panah-memanah, moedik djandjam (soengei) jang seni, kaoe balik kelaoet jang likat.

„Disitoe tempat kaoe.

„Djangan mentjobo menjikso anak Adam. 
„Kalau kaoe tidak maoe moendoer, kena soempah bebendoe Allah".

Deze bezweringspreuk wordt ook gebruikt bij het bestrijden van ziekten veroorzaakt door Radèn Koening (de geest van het water). Radèn Koening, zoo snel als een pijl (sepanah alam), wordt verzocht pijlsnel terug te gaan naar zijn verblijfplaats, de zee. Gehoorzaamt hij niet, dan wordt hij met de vloek van Allah bebendoe (waarschijnlijk een verbastering van Soebhanahoe) bedreigd.

Het bersaleh duurt ten hoogste 3 avonden en nachten.

Het bersaleh moedjoek duurt, evenals het beringin moedjoek, 3 nachten. Het bersaleh moedjoek geschiedt op dezelfde wijze als het bersaleh berobat, doch in grootscher stijl. Men noemt dit ,koeroeng". Het zieke kind (meestal zijn het jonge personen) wordt als het ware opgesloien en beveiligd tegen ziekten. Wanneer het kind besneden wordt, of wanneer het trouwt, wordt het van de band met den Sidi ontslagen (dikeloearkan). Hierbij wordt rijstemeel (tepoeng tawar) op zijn lijf gestreken. De Sidi krijgt dan een kain poetih cadeau. Niet zelden heffen de Sidi en het bevrijde kind bij deze ceremonie een groot gehuil aan, om als het ware daarmede te toonen hoezeer de thans verbroken band hen heeft verbonden.

Een onderdeel van het berdikir en bersaleh is het berêntak, d.w.z. het dansend stampen met de voeten. Een bijzondere wijze van berêntak is het vuurdansen, waarover in het werk van Van Dongen niet gesproken wordt. Deze wijze van berêntak heb ik ook alleen in Meranti Pandjang aangetroffen. Deze wijze van bezwering is zóó belangwekkend, dat ik gemeend heb de voorstelling welke ik te Meranti Pandjang heb bijgewoond uitvoerig te moeten weergeven.

In den avond worden vuren ontstoken, die de toeschouwers en de omgeving rossig verlichten. Vóór den malim, die gebogen zit, staat een damarlampje. De malim, wiens bovenlijf ontbloot is, draagt een wonderlijke hoofdtooi, voorzien van belletjes. Deze hoofdtooi heet pajoeng.

Vóór den malim liggen eenige voedingsstoffen en andere voorwerpen verspreid: 1). gepofte padi, 2). beras koenjit, 3). selasih, 4). mennjan, 5). dodol, 6). een poendjoeng van nasi koenjit + geroosterde kip, 7). een pinang-kolf, 8). de beringin (zie boven). De voedingsstoffen worden beademd en daarna enkele rijstkorrels in de lucht gegooid, bij wijze van offer aan de geesten.

Hierna trekt de malim een doek over zijn hoofd en ademt de geur 
en de rook van de smeulende mennjan in. Het hoofd wordt heirbij voortdurend in horizontale richting bewogen, zoodat de belletjes van de pajoeng onophoudelijk rinkelen. De malim prevelt daarbij tooverspreuken (djampi-djampi), waarin ook de naam van Allah en zijn Profeet genoemd wordt. Hierna verrijst de malim om wild zingend een dans uit te voeren, het bovenlichaam heen en weer wiegend, de knieën doorgezakt en de armen stijf gehouden. De vingers zijn daarbij naar achteren gebogen. Van tijd tot tijd valt de malim uitgeput achterover en rust in trance in de armen der omstanders. Het sombere onheilspellende van het door het damarlampje en het gloeiende vuur schaars en flakkerend verlicht schouwspel wordt nog geaccentueerd door de monotone begeleiding van den redabspeler.

Wanneer de malim uitgeput, met schokkend lichaam achterover hangt, komt zijn echtgenoote (de hoeloebalang) om hem op hooge schelle toon vlak bij het oor toe te zingen en hem, den bemiddelaar tusschen de stervelingen en den geestenwereld, tot deze aarde terug te roepen. Hierop neemt de malim twee waaiertjes in de hand en bootst dansend het vliegen van een vogel na, daarbij met zijn woorden duidend op den wensch om het vliedende leven van de zieke te volgen en dit terug te brengen. Daarna danst de malim in steeds dichter kringen om het vuur heen, totdat hij eindelijk na vele opwindende bezweringsformules te hebben geschreeuwd en gezongen, dwars door het vuur heen danst en de gloeiende vonkende sintels uiteentrapt. Af en toe raakt de malim zijn echtgenoote met zijn hoofdtooi aan, waarop deze weer haar hooge keelklanken uitstoot (pantau soemangat). Op het laatst raken sommige omstanders zóó begeesterd, dat óók zij achter den malim aanloopen, hem met de hand aanrakend. $\mathrm{Zij}$ zorgen er echter wel voor van de gloeiende sintels weg te blijven.

Wanneer de malim tenslotte het vuur geheel heeft gedoofd, is het doel van de voorstelling bereikt. De zieke is, door het dooven van het vuur bevrijd van zijn kwaal (dingin).

Bij zeer ernstige ziektegevallen worden 7 vuren aangestoken en duurt de bezwering van 's avonds 8 uur tot 's morgens 5 à 6 uur. Het eigenaardige is, dat aan de voeten van den malim nergens brandwonden zijn te bespeuren. Op mijn vraag of hij zonder in trance te zijn, ook door het vuur durfde te loopen, antwoordde hij, dat hij dan zeker brandwonden zou oploopen. De malim van Meranti Pandjang heet Rais bin Aliitam (zie onder $\S g$ ). Zijn grootvader was reeds malim. 
4). Andere, onder bovengenoemde categorieën niet vallende bezweringswijzen of geneesmiddelen zijn nog:

Berobat sakit pening (het bezweren van opkomende krankzinnigheid). Een sanggar (zie boven) van $5 \mathrm{M}$. hoogte wordt opgericht, bedekt met de gebruikelijke ingrediënten. De malim spreekt daarbij de volgende woorden:

„Salam alaikoem boemi langit.

„Akoe mengatoeri kamoe dahar sanggar

sebatang gebah dengan isi.

„Toekar teboes setimbang badan Poendjoeng

koening biring merah, koening kaki.

„Akoe atoer dengan kamoe.

„Salah silip minta' diampoen.

„Baliklah engkau ke awan-awan.

,Itoelah tempat setanèh engkau". ${ }^{1}$ ).

De beteekenis is duidelijk; den onheilbrengenden geest wordt verzocht in ruil van het slachtoffer (de patiënt) genoegen te nemen met de offeranden op de sanggar en te verdwijnen.

Berobat orang disoeban: Men gelooft, dat in een bron een geest huist, die koorts en stuipen veroorzaakt. Deze geest heet Roné; daarmee wordt ten rechte de regenboog bedoeld. Een sanggar wordt opgericht, ter hoogte van $11 / 2 \mathrm{M}$. en besprenkeld met het bloed van een zwarte kip en een rauw ei. In een kring rond de sanggar, op \pm . 3 meter afstand, worden 7 vuurtjes gestookt, welke door den malim worden uitgedoofd met zijn voeten (zie onder berêntak). Voordien spreekt hij de volgende woorden uit:

„Ja goeroe, ja goeri bara.

„Bergantoeng bawah lantai, ditepak djadi djin Beraoe.

„Terkintjang djadi balo Roné pandjang.

„Balik engkau kembali engkau.

„Baliklah keawan-awan.

„Itoelah tempat setanèh engkau.

„Djangan mentjobo menjikso anak Adam kasih Allah". ${ }^{2}$ )

1) Setanèh $=$ istana $=$ paleis. Baliklah keawan-awan beteekent: keer naar de wolken (het luchtruim) terug. Hiermede wordt bedoeld Bala Beroeang (zie boven).

2) De djin Beraoe $=$ djin Roné (zie boven). De regenboog wordt dus gevraagd achter de wolken te verdwijnen. Barah $=$ merah $=$ rood, of gloeiend; balo $=$ bala $=$ geest. 
Bezweringsformule bij ontmoeting met een tijger:

„Hak, hok, soemoem moekoem Ratoe Deroehoem, akoelah dalam kelamboe Allah.

„Titik Allah selisih menih.

„Ja, keoeloe, hak kenamamoe,

„Hak kata Allah”. ${ }^{1}$ )

Is men reeds door een tijger gebeten, dan legt men een aftreksei van samaragibladeren op de wond.

\section{Bezweringsformule bij een mocilijke bevalling:}

Op een bamboe vierkant platform (antjak) wordt, onder het huis van de betrokken vrouw, een pas geslachte en opengesneden kip gelegd. Tevens wordt mennjan aangestoken, waarvan de rook naar boven stijgt tot aan de plaats waar de vrouw zich bevindt. De malim spreekt daarbij als volgt:

„Poenti anak, poenti beranak.

„Poenti kesindai, poenti anak.

„Djangan mentjoba menjiksa, anak Adam kasih Allah.

„Balik seberang sana laoetan.

„Itoe tempat setanèh engkau.

„Dibawah kepajang tjoendoeng.

„Hak moelia namamoe engkau”. ${ }^{2}$ )

Middel tegen slangenbeet:

De zwartbruine rest van een gerookte pijp (dus nicotine e.d.) (tjandoe oentjoei) wordt op de wond gelegd. Het gif zou dan worden geneutraliseerd (oentjoei is een koeboewoord voor pijp).

Bezweringsformule bij de ontmoeting met een beer:

„Hak toendoek boeko raso.

„Tjengang Adam boengkam Allah”. ${ }^{3}$ )

1) Soemoem $=$ moekoem $=$ berlari; ratoe Deroehoem $=$ de koning der tijgers. (De woorden zijn tevens een klanknabootsing van het gegrom van den tijger, wanneer deze schrikt of boos is). Akoelah dalam kelamboe Allah = ik ben in de hoede van Allah. Titik = djatoeh (in ongenade vallen). Selisih = huidharen van den tijger. Menih $=$ poot van een tijger of kat. Ja $=$ engkau $=\mathrm{jij}$. Hak (ke)namamoe hak kata Allah $=$ je naam is het eigendom van Allah, d.w.z. Allah heeft je geheel in zijn macht, dus je kunt geen kwaad doen.

$\left.{ }^{2}\right)$ Poenti anak = poenti kesindai $=$ een booze geest, die het op kraamvrouwen voorzien heeft. Kepajang tjoendoeng (onder de ver verwijderde kepajangboom d.w.z. achter de horizon).

3) Toendock = takoet; boeko raso $=$ pengrasaan diboeka. De beer staat in 


\section{Bezweringsmethode tegen wilde varkens:}

Men kookt de bladeren van een boenglih struik, vermengd met stukjes gedroogde geitenhuid en het vet van een gedooden tijger en danganbladeren (ook een soort van boenglih). Nadat alles kookt, snijdt men dit mengsel in stukjes, welke men tusschen kleine aan het boveneinde gespleten bamboestokjes inklemt. Deze bamboestokjes worden daarna aan de rand van de ladang geplant. Wanneer het varken dit middel ruikt, vlucht het, en de ladang is gered.

\section{h. Muziek en zang.}

Muziekinstrumenten zijn de soeling, de gambang en de redab.

De soeling is een dwarsfluit van bamboetamiang vervaardigd. De bespelers, uitsluitend mannen, liggen daarbij bij voorkeur op den rug. Het instrument wordt 's ochtends vroeg en tegen het vallen van den avond bespeeld.

De wijsjes, die men voor mij gespeeld heeft, hebben de volgende namen:

1. lagoe babar lajar.

2. " tangis boedjang toea.

3. „ siamang be' tegoer.

4. „ tipa (taboeh) Lalan.

5. „, boedak dari ketjindoen (menjanji).

6. „ " pertjang naik goenoeng.

De lagoe siamang be' tegoer is een aardige klanknabootsing van de roep der siamangs.

Een ander instrument is de gambang. De gambang bestaat uit 4 stukken mahanghout van verschillende grootte. In dit geval wordt het aantal stukken hout met 2 uitgebreid. Deze stukken worden toonladdersgewijze op de uitgestrekte beenen neergelegd, waarna ze met een rond houten mahangstokje worden bespeeld. De tonen, welke op deze wijze ontstaan, zijn licht en korttokkelend. Hoewel de aldus ver-

zijn aanvalhouding, met de bek open en de voorpooten uitgestrekt, doch door de macht van Allah wordt de bek weer gesloten zonder dat de beer kwaad gedaan heeft. Tjengang $=$ lemah $=$ zwak, krachteloos; boengkam $=$ toovermiddel waardoor iemand tijdelijk van zijn spraak (of kracht) wordt beroofd. (Zie klinkert Maleisch-Nederlandsch woordenboek 3e druk pagina 105 le kolom. Mogelijk is ook dat hier bedoeld wordt bongkang, d.w.z. bewegingloos op den grond liggend, zooals een doode of onmachtige met de stuit naar boven (Klinkert pag 164, le kolom). 
kregen muziek uiteraard primitief is, gaat daarvan een zekere bekoring uit.

De gambang wordt door vrouwen bespeeld. Hierover sprak ik reeds in een ander verband. Het geluid van de gambangtonen is over meer dan 1 K.M. afstand te hooren. Het aantal wijsjes bedraagt ongeveer 30. De lagoe taboeh larangan wordt gespeeld door de vrouw, wanneer zij de hulp van haar man, die op de ladang werkt, bij een klein ongeval noodig heeft. De lagoe Loeboek Ngadjang wordt door één vrouw op 6 gambang tonen gespeeld. De eenige vrouw, die deze lagoe nog kan spelen is Djènap bin Resoegoe, de echtgenoote van den malim van Meranti Pandjąng, Rais bin Aliitam. Het gebruik van de gambang sterft uit; de jongere generatie kan het instrument niet meer bespelen.

Een ander muziek- of liever begeleidingsinstrument is de redab. De redab wordt uitsluitend gebruikt bij verdrijving van ziekten. Elke ziektebezwering wordt begeleid door een verschillende trommelslag. Als voorbeelden noem ik:

Taboeh sekintjoeng (e.s.v. vogel). De ziel (levensgeest) van de zieke is weggevlogen als een vogel. Door het slaan van de taboeh sekintjoeng tracht men de vluchteling terug te lokken.

Taboeh nengkoda (njawa of napas), wordt gespeeld bij zeer ernstige ziekten.

Taboeh berkebalo (menolong penjakit). Wanneer iemand door booze geesten is bezeten, worden deze met behulp van deze taboehan verdreven. Hieronder volgt de tekst van de taboeh berkebalo:

Hoeai hoe salam semalai melaikoem boemi.

Salam semalai malaikoem langit.

Salam semalai malaikoem seradja toeboeh.

Salam semalai malaikoem seradja badan.

Bergentar-gentar diboemi.

Bergoeloeng dilangit.

Beringoeng laoet semoela djadi.

Beringoeng serta se-isinja.

Boedjang padendang dirantau laoet.

Timboel ngapo tjoba ditoeboeh.

Timboel ngapo tjoba dibadan.

Hendak otak diganti otak.

Hendak darah diganti darah.

Hendak daging diganti daging. 


\author{
Orang seorang digenti doea. \\ Datang engkau kembali engkau. \\ Datang kerintik (druppel) hoedjan panas. \\ Balik kerintik hoedjan panas. \\ Datang engkau kesindja petang. \\ Balik engkau kesindja petang. \\ Datang engkau ketengah malam. \\ Balik engkau ketengah hari. \\ Boekan sini kedoedoekan, anak Adam toea sekali. \\ Allah lagi kekasih. \\ Mohamad lagi agam (kekasih). \\ Masoek tawarkoe, keloear bisamoe.
}

De bedoeling is dus dat de onheilbrengende geest wordt bevolen op zijn schreden terug te keeren (het verwoeste te herstellen). Hem wordt gezegd: ,,je hoort hier niet thuis”. Aan het eind wordt met luiderstem gesproken: „Dat mijn geneesmiddel zijn werk verrichte”. „Dat je vergift (van den boozen geest) verdwijne”.

\title{
i. Pantoens :
}

In de Koeboestreken kent men velerlei pantoens. Het meest beroemd zijn de ,pantoen toeloeng beroendingan", d.w.z. de pantoens, die als hulpmiddel dienen bij het maken van afspraakjes tusschen boedjang en gadis. Beroendingan is synoniem met berasan, onderhandelen, overeenkomen, dus afspraakjes maken. Deze pantoens worden op langzame gerekte wijze gezongen.

Ik heb getracht de melodie daarvan op muziek te zetten, waarvan hieronder een proeve volgt. Uitdrukkelijk zij echter aangeteekend, dat de zuivere weergave van de vaak verglijdende en voor onze ooren wat onzuivere toonen, nooit volkomen kan worden bereikt. Vooral dient erop te worden gelet, dat de verschillende woorden en lettergrepen niet te gescandeerd worden gezongen; de verschillende klanken vloeien in elkaar over. 

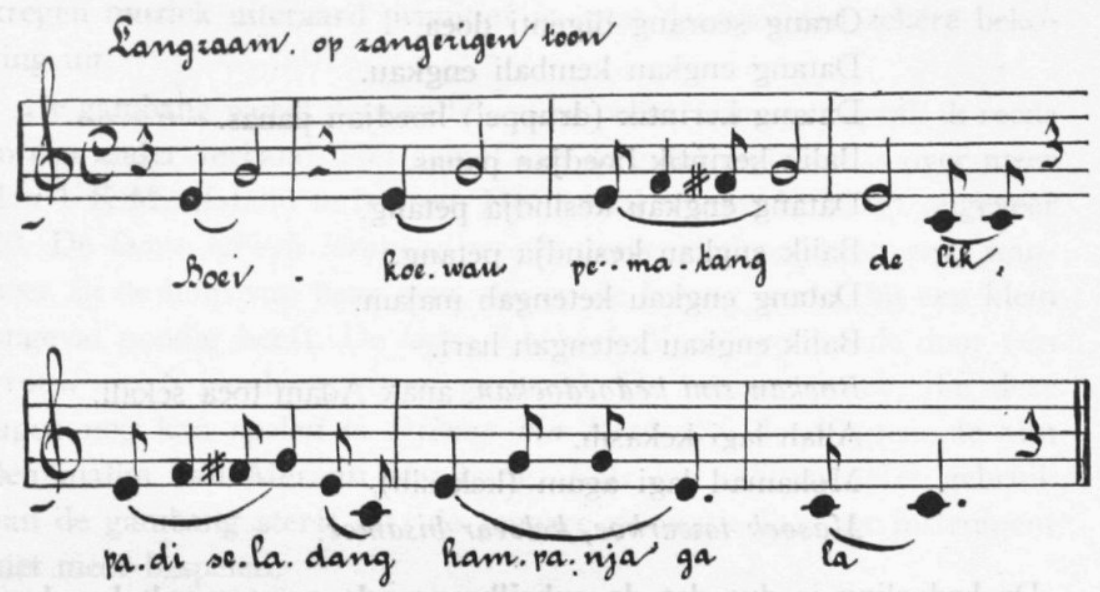

De eerste twee regels van de pantoen zijn hierboven op muziek gezet. De derde en vierde regel worden weer op dezelfde wijze gezongen. Voor elke pantoen is de zang precies hetzelfde; variatie bestat dus niet.

Thans worden enkele dezer pantoens hieronder weergegeven; de eerste twee regels vormen slechts een inleiding en hebben meestal geen beteekenis, welke op het onderwerp in kwestie slaat.

I. 1. Boei koeau pematang delik

2. Padi seladang hampô-nja galo.

3. Kalau ada antjaman bai

4. Kami terboeang tidak mengapo.

II. 1. Tarik rotan dilelatjak

2. Mandi diloeboek asampiat.

3. Kalau bermain sama patja'

4. Tiroe keboeboek asampiat.

III. 1. Akar djitan akar serti

2. Serti batang serpat.

3. Ketjil itam raga merti

4. Kata didalam djarang dapat.

IV. 1. Menebang kajoe tempoeroeng

2. Ketitik daoen ketari.

3. Kira ma' akoe djadi boeroeng

4. Senang terbang balik hati. 
V. 1. Menebang tjempedak besar

2. Roewat menimpa tandjoeng poetoes.

3. Ombak besar tidak rega

4. Asal redjoeng sama toeloes.

VI. 1. Ambil sambang boeloeh berteboek

2. Kelintang kebatang kajoe ara.

3. Redjoeng terkambang tengah teloek

4. Nanti pasang di moeara.

VII. 1. Riboe riboe djalan ke Betoeng

2. Roempoet manis bertaroeh moeda.

3. Nadjin seriboe toembak mengepoeng

4. Itam manis koepangkoe djoega.

VIII. 1. Kemerandjat ladjoe ke Beti

2. Singgah merapat Soengei Doea.

3. Niat adjat sesangi hati

4. Maoe sekoeboer kita doea.

IX. 1. Terkoekoe terbang moedik

2. Hinggap diranting koeang-koeang.

3. Kalau rindoe pesankan balik

4. Banjoe mata djangan diboeang.

X. 1. Raoe-meneraoe riboet panas

2. Emboen kemimboen boengo teboe.

3. Tangis Siamang ooeloe Rawas

4. Tjakap mengempang goenoeng Dempo.

XI. 1. Nadjin tidak mandi di Moesi

2. Datang ketebat mandi djoego.

3. Nadjin tidak djadi diboemi

4. Datang ke-hérat djadi djoego.

XII. 1. Selasih alang kemalang

2. Kajoe hidoep dilarap api.

3. Kalau kasih djangan kepalang

4. Dari hidoep sampai kemati.

XIII. 1. Tinggi kapas dipoelau Pinang

2. Lebat boeah bedaro djaoeh.

3. Asal napas lagi djemenang

4. Kaoe koeangkat tali njaoe. 
XIV. 1. Alangkah sajang (a)sam piat laboe

2. Laboe ditanam bidadari.

3. Alangkah sajang hoetan djaoeh

4. Tidak teroelang oleh kami.

XV. 1. Hendak mandi tekan kebatoe

2. Singgah berempat Soengei doea.

3. Kalau hendak mati adi pesan (k) akoe

4. Nanti sekoeboer kita doea.

XVI. 1. Nadjin tidak mandi dibatok

2. Datang keminak mandi djoego.

3. Nadjin 'endak djadi samo kito

4. Datang keanak djadi ke-djoego.

XVII. 1. Kemana njirim ketjioem

2. Dikirim kepado pagar sasak.

3. Kemano njirim ketjioem

4. Kirim kepada 'mbatjang masak.

XVIII. 1. Berdêkêr koekoe baboei

2. Simbati lais dalam peti.

3. Simbati aro dibawah pelantar

4. Rami tangis siboeroeng boengkai.

5. Hendak mengarang kembang meleboeai

6. Kembang aloes dipoetjoek tinggi.

Verklaring van enkele woorden en de beteekenis der pantoens:

I. 1 . boe $i=$ bitjara (taal van Meranti Pandjang).

koeau $=$ argusfazant (zie Klinkert Mal. Nederl. woordenboek, 3e druk, pag. 835). De koeau meet van kop tot staart \pm 1 Meter; het vleesch moet zeer smakelijk zijn. Het woord koeau is eigenlijk een klanknabootsing van de roep van de argusfazant; deze klinkt namelijk ongeveer als volgt: koe - eh - hoe - hoe.

delik $=$ rimba $=$ oerwoud.

De laatste 2 regels duiden op de onverzettelijk liefde, die geen bedreiging en verstooting vreest.

II. 1. lelatjak = rawang? waarschijnlijk moet gelezen worden leletjek $=$ poel van stilstaand regenwater. Het praefix $l e$ - is een frequentatief van het substantief letjak. (Zie Klinkert, pag. 911).

II. 2. Asampiat $=$ een wilde vrucht die ongeveer als een embatjangvrucht smaakt. 


\section{3. patja' $=$ pandai $=$ bisa.}

4. boeboek $=$ klander, kleine zwarte torretjes in de rijst en in vruchten. (Zie Klinkert, pag. 199).

De beteekenis van de pantoen (de 2 laatste regels) is, dat tijdens het schertsen, gekheid maken, de liefde steelsgewijze het hart van de jonge vrouw binnendringt, zooals de klander de asampiat binnendringt.

III. 1. djitan $=$ e.s.v. wortel; serti $=$ idem, doch kleiner.

2. $\operatorname{serpat}=$ sepotong (wellicht seperempat?).

3. $m e r t i=$ begrijpen. Merti is een samentrekking van mengerti (begrijpen); raga $=$ seperti; te Meranti Pandjang gaf men althans deze verklaring van het woord. Het is mogelijk dat het woord verwant is aan regâ of harga (dus: evenveel waarde bezittend als ...).

De bedoeling van regel 3 en 4 is: $\mathrm{Al}$ ben je ook klein (onoogelijk) en zwart, dat doet er niet toe, als je mij maar begrijpt (met mij harmonieert), hetgeen niet zoo heel gemakkelijk is; het hart spreekt een verborgen taal.

IV. 1. tempoeroeng $=$ de helft van een kokosdop of de boeah tempoeroeng $=$ advocaatvrucht. (Zie Klinkert, pag. 301, 1e kolom):

2. ketitak $=$ een kleine boom; ketar $i=$ een grassoort.

3. $m a^{\prime}-a k o e=\ldots \ldots$ ik.

Ma' is een uitroep welke ook in de Moesistreken wordt gebruikt, b.v. ma' mané $=$ bagaimana $=$ hoe dat. Ma' akoe is dus het beste te vertalen door ,wat mij betreft".

De beteekenis van regel 3 en 4 is: Wanneer ik een vogel was, dan vloog ik (terug) naar het hart van mijn geliefde.

V. 2. roewat $=$ roeboeh $=$ vallen.

3. $r e g a=$ harga $=$ waarde, nut.

4. redjoeng $=$ sampan $=$ kleine prauw ; toeloes $=$ oprecht, eens van zin.

Beteekenis van regel 3 en 4 is: Groote golven worden niet gevreesd, indien de prauw (het huwelijksbootje) eensgezind, (recht) wordt gestuurd.

VI. 1. sambang = bamboe die als waterdrager wordt gebruikt?

Volgens Klinkert op pagina 589 beteekent sambang een verlaten bijennest of nog versche honigraat of padi sambang $=$ mislukt rijstgewas. De eerste vertaling ligt echter in verband met de volgende 
twee woorden wel het meeste voor de hand, te weten "Neem een „bamboe waterdrager waarin een opening is aangebracht".

2. lintang $=$ dwars.

3. redjoeng $=$ sampan; terkambang $=$ terbalik $=$ omgeslagen.

4. pasang $=$ dobberen, zich bevinden.

Beteekenis van regl 3 en 4: De jonge vrouw laat zich door niemand en niets afleiden en wacht geduldig op haar geliefde (zooals een omgeslagen prauw rustig naar de riviermond drijft).

VII. 2. bertaroeh moeda $=$ keloear moeda (bertaroeh beteekent eigenlijk wortelvatten).

3. nadjin $=$ seperti $=$ zooals $;$ mengepoeng $=$ omgeven.

Beteekenis van regel 3 en 4: Zwart en zoet (Voorspoed en tegenslag) aanvaard ik, als ik maar met mijn geliefde vereenigd kan worden.

VIII. 2. merapat $=$ berdekatan $=$ in de nabijheid van.

3. niat $=$ adjat $=$ sesangi $=$ bedoeling, wensch, verlangen.

Beteekenis van regel 3 en 4: De geliefden willen zelfs nog in den dood vereenigd zijn.

IX. 1. Terkoekoe $=$ e.s.v. duif. (Zie Klinkert, Ned. Mal., pag. 156 , terkoekoer).

2. Hinggap $=$ neerstrijken op; ranting koeang-koeang (koeangkoeang is naar men mij mededeelde e.s.v. hout). Het is mogelijk dat met koeang-koeang aangeduid wordt de klanknabootsing van een argusfazant; koeang $=$ koeau).

Beteekenis van regel 3 en 4: Wanneer je naar mij verlangt, zend dan een boodschap om mij terug te roepen en vergiet geen tranen (want ik kom bij je).

X. 1. Raoe-meneraoe riboet panas. (De beteekenis der woorden wist men mij niet te verklaren). Mogelijk wordt hier bedoeld merajau = rajap $=$ onrustig, woelig zijn. (Zie Klinkert, Maleisch-Nedelandsch, pag. 488).

2. Emboen $=$ dauw $;$ Emboen kemimboen $=$ bepareld van dauw.

De beteekenis van regel 3 en 4: Het verlangen van den jongeling reikt zóó ver tot aan de plaats waar de siamangs van Rawas roepen. Zijn liefde kan bergen verzetten (letterlijk de Dempo afsluiten of afdammen).

XI. 1. nadjin $=$ seperti $=$ zooals, of ook indien.

Beteekenis van regel 3 en 4 : Kunnen de geliefden niet in dit leven 
vereenigd worden, dan zullen zij elkander in het hiernamaals toch ontmoeten.

XII. 1. alang-kemalang $=$ her en der verstrooid.

3. kepalang $=$ gering.

Beteekenis van regel 3 en 4: Wanneer je van mij houdt, laat het dan niet gering zijn (laat het geen spel blijven), maar laat deze liefde voor eeuwig zijn.

XIII. 2. lebat $=$ rijk, overvloedig.

3. djemenang $=$ selama-lama.

4. tali njaoe $=$ tali njawa.

Beteekenis van regel 3 en 4: Tot aan de laatste ademtocht zal ik je met mijn liefde binden. Ook is mogelijk dat tali njazwa een liefkoozingswoord beteekent; in welk geval de vertaling van regel 4 aldus luidt: Ik zal je dragen (opnemen), mijn liefste (d.w.z. het voornaamste, de levensvoorwaarde van mijn ziel (njawa).

XIV. 1. laboe $=$ pompoen, kalebas. (Zie Klinkert, pag. 891).

2. tidak teroelang $=$ niet te bereiken (zij kunnen er niet meer naar toe).

Beteekenis van regel 3 en 4: Het bosch is zóó ver verwijderd (het doel van onze liefde is zóó ver) dat wij het niet bereiken kunnen. (De jongeling of het meisje twijfelt aan de mogelijkheid van een vereeniging).

$\mathrm{XV}$. De beteekenis van regel 3 en 4 is duidelijk; de geliefden willen zelfs in den dood vereenigd zijn.

XVI. 2. batok $=$ kokosdop; kemina' $=$ waarschijnlijk kemana.

Beteekenis van regel 3 en 4 : Indien wij werkelijk het samen eens zijn, dan zullen, hoewel wij zelf niet kunnen trouwen, onze kinderen later toch een paar worden.

XVII. 1. ketjioem $=$ tjioem $=$ kus.

2. $s a s a k=$ sesak $=$ dicht op een.

Beteekenis van regel 3 en 4: De jongeling kust een rijpe embatjang vrucht en zendt deze aan zijn geliefde als een teeken dat hij in gedachten steeds bij haar vertoeft.

XVIII. 1. berdèkèr $=$ berboenji; rinkelen, krassen, snerpen; kaboea $=$ gondang e.s.v. zoetwaterslak. (Zie Klinkert, pag. 879).

2. simbati $=$ mendjawab. Het is mogelijk dat simbat in verband 
staat met samboet $=$ ontvangen, overnemen; dus het woord (van een ander) overnemen $=$ antwoorden.

4. koengkai $=$ e.s.v. vogel met een lange snavel, wiens geluid als volgt klinkt: ki-ki-ki-ki.

De beteekenis van regel 5 en 6 is: De koengkaivogel wil een schoone, teere melaboeai-bloem plukken, die eigenlijk te mooi, te fijn voor hem is. (De jongeling bezingt de hoedanigheden van zijn meisje en vergelijkt haar met een mooie bloem; het past hem eigenlijk niet deze bloem, die te mooi en te hoog voor hem is, te plukken.

\section{j. De verhouding der Koeboes tot de Maleiers.}

De vraag rijst, wie zijn de oorspronkelijke bewoners van Zuid en Midden Sumatra? Bestaat er verwantschap tusschen de Koeboes en Maleiers; waardoor wordt deze gekenmerkt?

Een inzicht in dit belangrijk vraagstuk kan verkregen worden door bestudeering van het werk van Paul Schebesta, getiteld Orang Utan (Leipzig 1928). Schebesta heeft in zijn beschouwingen mede opgenomen een volksstam op het Maleisch schiereiland, de Semilai-Jakoeden aan de Triang-rivier en de Kerau.

De orang-boekit, zoo noemen zich de Jakoeden met voorliefde, hoewel zij langs de rivieren in het laagland wonen, leefden, volgens de overlevering, vroeger in Sumatra. Daar (in Sumatra) leefden drie broeders, waarvan de jongste door de bevolking als radja werd erkend. De twee oudste broers waren hierover zóó verontwaardigd, dat zij de bosschen introkken. Een hunner kwam tenslotte in Djohore terecht, terwijl de andere naar Pahang trok. Aan de bovenloop van de Kerau ontmoette hij wonderlijke menschelijke wezens, die uit de Batang Seraia (een boomsoort) gesproten zouden zijn. Met deze lieden vermengde hij zich en nam hun spraak over. Zoo ontstonden de orang boekit. Oorspronkelijk waren zij echter Maleiers. De wezens, die uit de batang seraia ontsproten waren, zijn de negrito's die tot op den huidigen dag zich met de lieden van de Kerau vermengen (Schebesta, pag. 185). De Kerau en Semilai Jakoeden spreken een taal welke niet Maleisch is. Van zeer veel belang is echter het feit dat de bezweringen in het Maleisch, en wel in een archäsche vorm worden uitgesproken. Schebesta komt daarom tot de volgende belangrijke slotsom: „Es „kann wohl keinem Zweifel unterliegen, dass die Ursprache aller Jakudn die malaische in einer älteren Form war".

Schebesta vergelijkt voorts de Jakoeden met de Koeboes, die 
uiterlijk veel gelijkenis vertoonen. De Jakoeden hebben evenals de Koeboes een malim, die de ziekten uitdrijft. Ook bij de Jakoeden wordt daarbij de zelfde hoofdtooi (pajoeng) gebruikt (pag. 234).

Over de eenheid van taal, welke oorspronkelijk bij beide groepen geheerscht heeft, zegt Schebesta het volgende: „Dass Kubu und „Jakudn von Haus aus ein und dieselbe Sprache reden, ist mir keinen „Augenblick zweifelhaft. Die Versuche für die Kubu ein eigenes „Idiom aufzustellen, dürften nach den Aufstellungen van Dongens „,als gescheitert gelten. Woher kommt diese Übereinstimmung, da ,doch Kubu und Jakudn schon jahrhundertelang getrennt vonein„ander leben, getrennt durch einen Meeresarm? Tatsächlich wissen „,sie heute nichts voneinander. Man könnte sich damit ausreden, dass „,beide die gleiche Kultur von den Malaien, und zwar weil die Kubu „erst kürzlich zur Kultur übergegangen sein sollen, von den Moham,medanischen Malaien übernommen haben. Dagegen spricht aber ,schon die Tatsache, dass Kubu- und Jakudn Kultur in vielen Stü„,ken von der malaiischen verschieden ist. Wohl aber kann man „daraus folgern, dass Kubu und Jakudn früher einmal ein Volk „,waren. $\mathrm{Da}$ aber auch die Malaien dem Wesen nach die gleiche Kul„tur haben, müssen auch sie vordem, ehe sie Mohammedaner wurden, ,ein den Kubu Jakudn ähnliches und verwandtes Volk gewesen sein. „Kubu und Jakudn haben uns die alte malaiische Kultur unverfalsch"ter bewahrt als die Malaien selber" (pag. 259).

Ik meen, dat de conclusies van Schebesta de waarheid dicht benaderen.

Pogingen mijnerzijds om in wezen van het maleische idioom geheel afwijkende Koeboe-woorden aan te treffen, hebben niet het door mij oorspronkelijk verwachte resultaat gehad. De meeste, op het eerste gezicht afwijkende woorden, kunnen herleid worden tot de overeenkomstige Maleische uitdrukkingen; veelal heeft klinker-verwisseling en -vervorming plaats gehad. Van Dongen wijst er reeds op (pag. 200) dat, behalve in de Rawas-streek, waar vermenging met het Redjangsch heeft plaats gehad, de Koeboes vrij zuiver Maleisch spreken. In zijn artikel „Nog een en ander over de Koeboes” (verschenen in de Bijdragen van het Kon. Instituut, dl. 67, 1913) wijdt Van Dongen een hoofdstuk aan het dialect der Koeboes. Hoewel Van Dongen de mogelijkheid van een eigen oorspronkelijke taal der Koeboes niet ontkent, bestrijdt hij tegelijkertijd de z.g. niet-Maleische oorsprong van vele door B. Hagen „Die Orang Kubu auf Sumatra” opgetee-

D1. 99. 
kende woorden. Het bleek namelijk, dat door de onvoldoende kennis van het Maleisch van laatstgenoemden onderzoeker, vele, gemakkelijk op het Maleisch terug te brengen woorden, abusievelijk als oorspronkelijke Koeboewoorden werden aangemerkt.

Over de uiterlijke gelijkenis der Koeboes met de Maleiers, zegt Schebesta: „Man kann ihm (de Koeboe) nicht mehr zu den klein„wüchsigen zählen; auch schlankere Kubu sind unter den Männern ,nicht selten. Die Hautfarbe ist dunkelbraun, vielleicht etwas dun„kler als jene der Flussmalaien. Seine Haare sind straff, manchmal „zur Welligkeit geneigt. Bartwuchs ähnlich jenem der Malaien, wo„,bei der Schnurrbart besonders auffällt, kann bei den Kubu oft ,beobachtet werden. Selten wird man einen sauberen Kubu von „einem Malaien unterscheiden können, so dass ich kaum glaube, dass „,viel Beimischung fremden Blutes in der Kubuschicht vorhanden ist”. Op dezelfde bladzijde vermeldt de schrijver nog: „Ob vielleicht eine „negritische Blutmischung in einzelnen Kubu vorhanden ist, kann ,,ich nicht entscheiden, es mag aber sein, dass einzelne Individuen in ,ihrer Umgebung etwas auffallen. Dass vorherrschende Element ist "aber das malaiische".

Ik zou hierbij willen opmerken, dat verschillende Koeboes een wat langere en smallere schedelvorm hebben dan de Maleiers, terwijl zeer blanke typen door mij werden aangetroffen. Het is echter mogelijk, dat deze laatste maleisch bloed hebben. Dat de Koeboes in eenig opzicht wezenlijk van de Maleiers te onderscheiden zouden zijn, meen ook ik in het algemeen te moeten betwijfelen.

\section{k. De toekomst der Koeboes.}

Van Dongen meende (in 1913), dat weldra weinig meer van den natuurstaat van de Koeboes zou zijn overgebleven. (,Nog een en ander over de Koeboes"). De civiel gezaghebber te Bajoeng Lintjir had namelijk in de tweede helft van 1910 het volgende gerapporteerd: „Een fijn geschoeide Koeboe, met keurige sarong en zwarte ,jas aan, etende rijst met een blikje zalm en drinkende daarbij een "glaasje limonade, is tegenwoordig geen zeldzaamheid meer". Van Dongen teekende daarbij aan, dat hij zich de civilisatie en de vooruitgang in welvaart dezer Koeboes niet zoo vlug had gedacht. Het is echter gebleken, dat deze zoogenaamde civilisatie in werkelijkheid lang zoo snel niet is gegaan. Het verhaal van bedoelden civiel gezaghebber dateert van 1910, toen de bevolking in en om Bajoeng Lintjir 
abnormaal groote sommen gelds verdiende met het verzamelen en verhandelen van djeloetoeng. Bij het waardeloos worden van djeloetoeng verdween de fijn geschoeide en limonade drinkende Koeboe weer geruischloos naar zijn doesoen of bosschen. Te betreuren valt zulks niet; een dergelijke kunstmatige en abnormale ,civilisatie” kan weinig goeds en veel slechts veroorzaken.

Wel valt een geleidelijke assimilatie van de Koeboes met de Maleische bevolking te bespeuren. Deze assimilatie wordt vergemakkelijkt door verschillende factoren. In de eerste plaats is, zooals boven werd uiteengezet, de Koeboe niet een zoo van de Maleiers onderscheiden wezen; om een voorbeeld te noemen vormt de taal een belangrijke band. Anderzijds staat de Maleische bevolking in de Koeboestreken ook niet op een hoog peil van ontwikkeling. Het zijn vaak lieden, die met moeite en ongemak zich een poover bestaan kunnen verschaffen.

Ook hun godsdienstige voorstellingen en gebruiken zijn nog doorweven met tal van heidensche gedachten en survivals, waardoor eventueele overgang van de Koeboes tot den Islam zonder groote schokken en wijzigingen in hun levensbestek en -verhoudingen kan plaats vinden. Zooals in hooger verband reeds werd gemeld, zijn de Koeboes van Koeboe Bajat, Toengkal Oeloe, Dawas en Batang Hari Leko vrijwel allen tot den Islam overgegaan. Zij zijn opgenomen in de Maleische doesoenbevolking en geven en nemen aldaar ten huwelijk.

Nog heidensche Koeboes leven in de marga Pinggap (Talang Medang Tjelengkong en Talang Saoet) en in en bij de marga Koeboe Lalan. Alle Koeboes dezer onderafdeeling zijn echter geregistreerd en wonen in of in de nabijheid van doesoens of talangs. In de doesoen Mangsang, de pasirah-doesoen van Koeboe Lalan, bestaat ongeveer de helft der heerendienstplichtigen uit heidensche Koeboes. In de overige doesoens is de verhouding ongeveer dezelfde. Ik schat mitsdien het totaal aantal werkbare Koeboemannen, die den Mohammedaanschen godsdienst niet belijden, op ten hoogste 150 , zoodat het aantal tot deze categorie behoorende zielen op \pm 600 kan worden gesteld. Het overgroote geedeelte van deze lieden vertoeft in de marga Koeboe Lalan. De reden hiervan ligt voor de hand. Hier is het jachten zamelgebied nog uitgestrekt, zoodat de Koeboes hier nog niet zoo zeer, of althans niet in die mate als in andere streken dezer onderafdeeling het geval was, uit overwegingen van zelfbehoud genoodzaakt waren zich met de Maleische bevolking te assimileeren.

Een overgangsstadium treffen wij aan bij de in de doesoens van 
Koeboe Lalan gevestigde niet Mohammedaansche Koeboes. De laatste band die hen aan hun vroeger bestaan nog bindt is hun niet toetreden tot den Islam; terwijl zij min of meer achteraf wonen, elkanders gezelschap zoeken en gaarne lang en vaak de doesoen verlaten.

Zwervende Koeboes, die v.z.v. bekend geen contact met de Maleische bevolking, laat staan het Bestuur hebben, komen in de uitgestrekte moerasbosschen tusschen de Lalanrivier en de grens met Djambi nog wel voor. Enkele recente gevallen hebben dit uitgewezen. Omstreeks den 15den December 1937 hebben koelies van de N.K.P.M., die bij de Soengei Merang exploratiewerkzaamheden verrichtten, een ontmoeting gehad met een dergelijke groep Koeboes van ongeveer 10 personen. Zij hebben rijst uit de goedang medegenomen en een koeli verwond. Tien dagen nadien zijn 12 inwoners van de doesoen Poeli Gading (Koeboe Lalan) gestuit op ongeveer 10 zwervende Koeboes; die slechts gekleed waren in een schaamgordel van boombast, terwijl het hoofdhaar tot aan de schouders reikte. Deze Koeboes hebben de vrouwen van de lieden van Poeli Gading bedreigd en haar rijst, klamboes en andere ingrediëten uit de pondok meegenomen. Hierover handelt uitvoerig mijn schrijven van 22 Maart 1938 No. 4065/23, gericht aan den Afdeelingschef. Door mij werd n.h.v. op goede gronden verondersteld, dat de aanvallers afkomstig zijn uit de bosschen en moerassen van Djambi, doch dat zij door honger gedreven steeds verder doordringen tot de Lalanrivier, teneinde aldaar voedsel van de aanwezige bevolking weg te halen. Het zij mij vergund het slot van mijn brief in dit verband te citeeren, aangezien hieruit mijn meening over de toekomst dezer Koeboes en het standpunt dat van Bestuurszijde terzake dient te worden ingenomen, n.h.v. duidelijk wordt weergegeven. „Ik zie in deze aanvallen wanhoopspogingen van ,beklagenswaardige desperado's die hun vrijheid en luiheid niet willen „opgeven; het is waarschijnlijk een steeds kleiner wordende groep, ,aan de eene kant bedreigd door de door hen zoo gevreesde assimilatie „met de Maleische bevolking en aan de andere zijde door het dage„lijks dringend voedselgebrek. Kan of moet hier hulp verleend wor,den van Bestuurszijde? Ik geloof het niet; de honger zal op den „,duur hen ertoe drijven hun vrijheid (die overigens zeer betrekkelijk ,is) op te geven. Wellicht zal een volgende generatie met schaamte ,denken aan hun voorouders, die in de bosschen zwierven; ook voor ,den Koeboe gaat het levenstempo sneller tegenwoordig. Hoewel over ,dit onderwerp uiteraard verschillend gedacht kan worden, meen ik, 
„dat assimileering, onder zekere voorwaarden, slechts toejuiching ver„dient; de natuurstaat der Koeboes is niet zoo heel erg ideaal”.

\section{T a a 1.}

Over de taal der Koeboes is in hooger verband reeds gesproken. Daarbij werd erop gewezen, dat deze taal in wezen niet veel van die der Maleische bevolking verschilt. De meeste op het eerste gezicht afwijkende woorden komen voor in de pantoens, welke in de Koeboestreken worden gezongen. Niet vergeten dient echter te worden dat in pantoens vaak oude of verouderde woorden worden gebruikt, die in de dagelijksche spreektaal, ook vroeger niet, waarschijnlijk geen of weinig burgerrecht hebben verkregen. In de pantoens der Moesimarga's komen ook dergelijke, thans niet meer thuis te brengen woorden of uitdrukkingen voor.

Enkele woorden, in de Koeboestreken gebruikelijk, volgen hieronder:

Tapak laoek angit $=$ een tijgerspoor (laoek $=$ vleesch, of in het algemeen voedsel); angit $=$ stinkend als semamboe angit. De naam tijger wordt dus omschrven, als het stinkend vleesch of de stinker).

Kioe $=$ kesitoe.

Kema'i = kemari.

Kelak $=$ nanti.

Mika $=$ kamoe.

Kemono mika $=$ kemana kamoe.

Pilat $=$ melihat $=$ zien.

Idap $=$ awas.

Idap $=$ hidoep ?

Be'légé $=$ berlaga $=$ vechten.

$\mathrm{Be}^{\prime}$ nèko $^{2}=$ elkaar plagen.

Noeai $=$ ketam $=$ oogsten.

Oentjoei $=$ pijp.

$\mathrm{Nio}=$ ini.

'Mba $=$ seperti.

Bangkar $=$ akar

Temiang $=$ e.s.v. bamboe.

Temiang berseri koening $=$ de temiang met den gouden glans $=$ padi.

Tjapô = bloekarhout.

$\mathrm{Bara}(\mathrm{h})=$ merah $=$ rood of gloeiend. 
Ketjindoen $=$ bernjanji $=$ zingen. Mogelijk is dit een samentrekking van ke-tjindoe-an of ke-rindoe-an, d.w.z. door liefde of verlangen bevangen. De jongeling die zich in zulk een toestand bevindt moet natuurlijk zijn liefde bezingen of liever befluiten.

Hoewel, zooals boven werd aangeteekend, in de pantoens verschillende vreemde uitdrukkingen voorkomen, vallen niet in de eerste plaats deze afwijkingen op, doch vooral de zuiverheid van het Maleisch en de goede woordkeuze en zinsbouw dezer gedichten; dit wijst erop, dat de taal der Koeboes in wezen niet van die der Maleiers verschilt. Niet vergeten dient te worden, dat de Koeboes, die zóóveel van hun eigen gebruiken en gedachtenwereld hebben behouden, ook zelfs na overgang tot den Islam, zeker de vertolkster dier gedachten en voorstellingen, te weten hun taal, min of meer zuiver zouden hebben bewaard indien deze taal inderdaad oorspronkelijk belangrijk van de Maleische afweek. Opmerkelijk is ook, dat bij de bezweringsformules en andere van ouds overgeleverde, met het geestesleven der Koeboes in verband staande, door woorden en zinnen tot uiting gebrachte gedachten, het Maleisch gebezigd wordt. Zouden de Koeboes oorspronkelijk inderdaad een eigen, van het Maleisch in wezen verschillende taal hebben gesproken, dan zouden hiervan in de bezweringsformules en andere gewijde teksten toch zeker overblijfselen moeten worden aangetroffen. Wel zeer duidelijk spreekt het voorbeeld der „Jakudn" van Schebesta; zooals boven werd vermeld, gebruiken deze lieden bij hun bezweringsformules een Maleisch idioom, terwijl hun dagelijksche omgangstaal een daarvan in wezen geheel afwijkende is geworden. Veilig kan dus worden aangenomen dat het „Koeboesch” in wezen „Maleisch” is.

\section{Godsdienst.}

Over de godsdienst, of althans het religieus besef van de Koeboes is in hooger verband reeds gesproken. Het complex van voorstellingen en gedachten dat de Koeboes ten aanzien van het immaterieële, of althans niet uitsluitend materieële zich hebben eigen gemaakt, kan m.i. zonder bezwaar als godsdienstig berenst-zijn worden aangemerkt. Volgens Olbrechts (Ethnologie, pag. 224 e.v.) dient hieronder te worden verstaan een berenstzijn afhankelijk te zijn van een buitennatuurlijke macht, die gewoonlijk persoonlijk gedacht is en de behoefte door handelingen met die macht betrekkingen te onderhouden. Menschen zonder ,godsdienst", in den bovenomschreven zin, "kunnen wij de Koeboes dus niet noemen. 